SRNL-STI-2010-00766

Revision 0

Keywords: Plutonium

disposition, glass

homogeneity, crystallization, glass durability

Retention: Permanent

\title{
PLUTONIUM SOLUBILITY IN HIGH-LEVEL WASTE ALKALI BOROSILICATE GLASS
}

\author{
J. C. Marra \\ C. L. Crawford \\ K. M. Fox \\ N. E. Bibler
}

December 2010

Savannah River National Laboratory Savannah River Nuclear Solutions, LLC Aiken, SC 29808

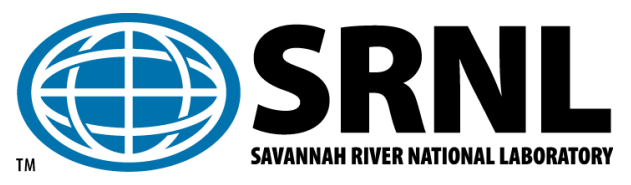


SRNL-STI-2010-00766

Revision 0

\section{DISCLAIMER}

This work was prepared under an agreement with and funded by the U.S. Government. Neither the U.S. Government or its employees, nor any of its contractors, subcontractors or their employees, makes any express or implied:

1. warranty or assumes any legal liability for the accuracy, completeness, or for the use or results of such use of any information, product, or process disclosed; or

2. representation that such use or results of such use would not infringe privately owned rights; or

3. endorsement or recommendation of any specifically identified commercial product, process, or service.

Any views and opinions of authors expressed in this work do not necessarily state or reflect those of the United States Government, or its contractors, or subcontractors.

\section{Printed in the United States of America}

\section{Prepared for}

U.S. Department of Energy 


\section{REVIEWS AND APPROVALS}

\section{AUTHORS:}

J. C. Marra, Materials Science and Technology Date

C. L. Crawford, Process Technology Programs Date

K. M. Fox, Process Technology Programs

Date

N. E. Bibler, Process Technology Programs

Date

TECHNICAL REVIEW:

D. K. Peeler, Process Technology Programs

Date

APPROVALS:

N. C. Iyer, Manager

Date

Materials Science and Technology

Date

S. L. Marra, Manager

Environmental \& Chemical Process Technology Research Programs

C. C. Herman, Manager

Date

Process Technology Programs 


\section{ACKNOWLEDGEMENTS}

The authors would like to recognize the invaluable support of the Savannah River National Laboratory (SRNL)-Environmental \& Chemical Process Technology Research Programs chemists and technicians for surrogate glass sample preparations and analyses; SRNL-Shielded Cells technicians and management for the in-cells work; SRNLMaterials Science and Technology and Environmental \& Chemical Process Technology Research Programs personnel for Pu glass sample preparations to facilitate analyses; and SRNL-Analytical Development researchers and technicians for surrogate and $\mathrm{Pu}$ glass analyses. 


\section{EXECUTIVE SUMMARY}

The solubility of plutonium in a Sludge Batch 6 (SB6) reference glass and the effect of incorporation of $\mathrm{Pu}$ in the glass on specific glass properties were evaluated. A Pu loading of 1 $\mathrm{wt} \%$ in glass was studied. Prior to actual plutonium glass testing, surrogate testing (using $\mathrm{Hf}$ as a surrogate for $\mathrm{Pu}$ ) was conducted to evaluate the homogeneity of significant quantities of $\mathrm{Hf}(\mathrm{Pu})$ in the glass, determine the most appropriate methods to evaluate homogeneity for Pu glass testing, and to evaluate the impact of Hf loading in the glass on select glass properties. Surrogate testing was conducted using $\mathrm{Hf}$ to represent between 0 and $1 \mathrm{wt} \% \mathrm{Pu}$ in glass on an equivalent molar basis.

A Pu loading of $1 \mathrm{wt} \%$ in glass translated to $\sim 18 \mathrm{~kg}$ Pu per Defense Waste Processing Facility (DWPF) canister, or about 10X the current allowed limit per the Waste Acceptance Product Specifications $\left(2500 \mathrm{~g} / \mathrm{m}^{3}\right.$ of glass or about $1700 \mathrm{~g} /$ canister) and about $30 \mathrm{X}$ the current allowable concentration based on the fissile material concentration limit referenced in the Yucca Mountain Project License Application $\left(897 \mathrm{~g} / \mathrm{m}^{3}\right.$ of glass or about $600 \mathrm{~g} \mathrm{Pu} /$ canister). Based on historical process throughput data, this level was considered to represent a reasonable upper bound for $\mathrm{Pu}$ loading based on the ability to provide Pu containing feed to the DWPF.

The task elements included evaluating the distribution of $\mathrm{Pu}$ in the glass (e.g. homogeneity), evaluating crystallization within the glass, evaluating select glass properties (with surrogates), and evaluating durability using the Product Consistency Test - Method A (PCT-A). The behavior of $\mathrm{Pu}$ in the melter was evaluated using paper studies and corresponding analyses of DWPF melter pour samples.

The results of the testing indicated that at $1 \mathrm{wt} \% \mathrm{Pu}$ in the glass, the $\mathrm{Pu}$ was homogeneously distributed and did not result in any formation of plutonium-containing crystalline phases as long as the glass was prepared under "well-mixed" conditions. The incorporation of $1 \mathrm{wt} \% \mathrm{Pu}$ in the glass did not adversely impact glass viscosity (as assessed using Hf surrogate) or glass durability. Finally, evaluation of DWPF glass pour samples that had Pu concentrations below the $897 \mathrm{~g} / \mathrm{m}^{3}$ limit showed that $\mathrm{Pu}$ concentrations in the glass pour stream were close to targeted compositions in the melter feed indicating that Pu neither volatilized from the melt nor stratified in the melter when processed in the DWPF melter. 


\section{TABLE OF CONTENTS}

LIST OF ABBREVIATIONS ........................................................................ ix

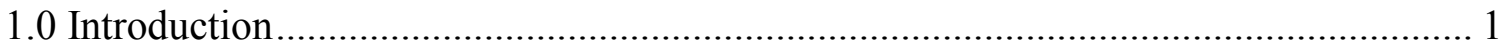

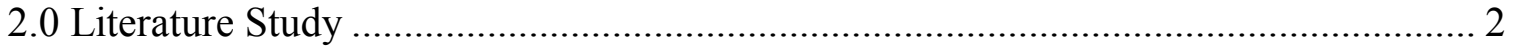

2.1 Plutonium Solubility in Glass ....................................................................... 2

2.2 Local Environment of $\mathrm{Pu}$ in Glass..................................................................... 4

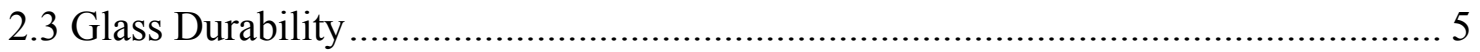

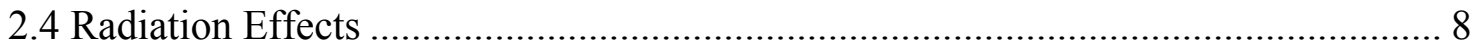

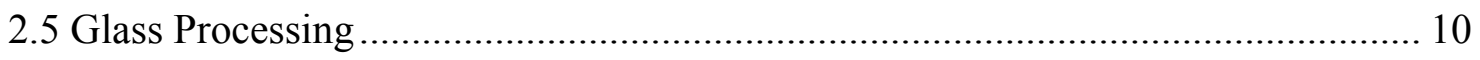

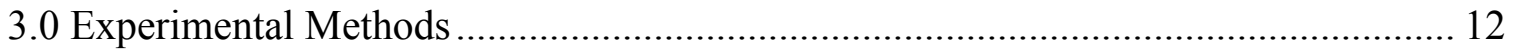

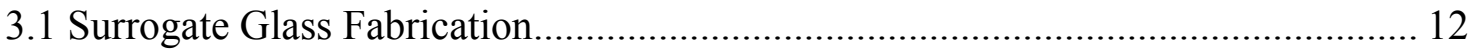

3.2 Plutonium Glass Fabrication .......................................................................... 12

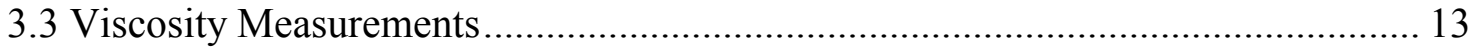

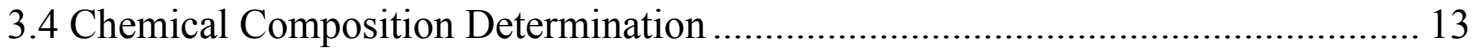

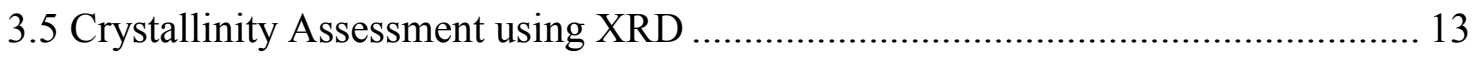

3.6 Homogeneity Assessment using Electron Microscopy ....................................... 14

3.7 Product Consistency Test to Determine Durability .......................................... 14

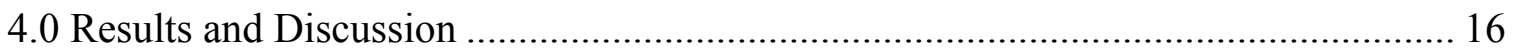

4.1 Viscosity Measurements on Hf Surrogate Glasses............................................ 16

4.2 Crystallinity Assessment in Hf Surrogate Glasses ............................................. 16

4.3 Homogeneity Assessment of Hf Surrogate Glasses .......................................... 18

4.4 Chemical Composition of the Actual SB6 Glass with $\mathrm{Pu}$.................................. 22

4.5 Crystallinity Assessment in Pu Glasses............................................................... 22

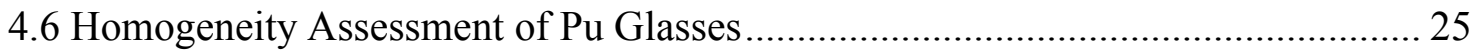

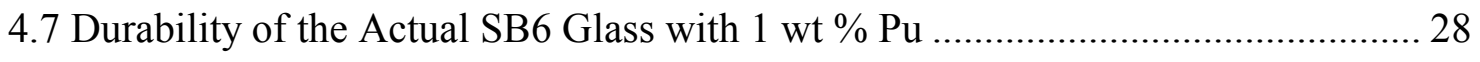

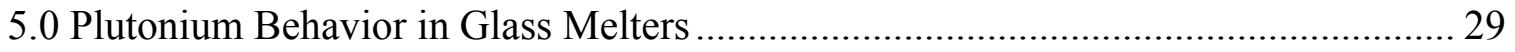

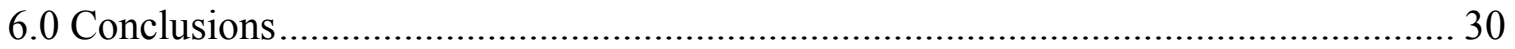

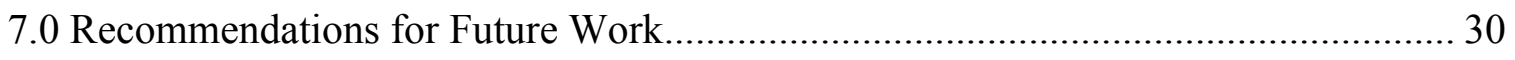

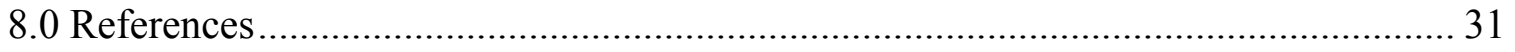

9.0 Appendix A................................................................ 


\section{LIST OF TABLES}

Table 1. Chemical Composition of Actual SB6 Glass with 1 wt \% Pu....................................... 22

Table 2. PCT Results for SB6 Qualification Glass and SB6 Glass with 1 wt \% Pu ................... 29

Table 3. Results of Pour Stream Pu Concentration Measurements for Two Melter Campaigns.. 29 


\section{LIST OF FIGURES}

Figure 1. Cumulative $\alpha$-decay dose as a function of plutonium loading and waste storage time - from Weber et al., 1997.

Figure 2. Schematic showing sectioning of glass "crucible-forms" for subsequent analyses using SEM/EDS.

Figure 3. Viscosity at $1150 \mathrm{C}$ for a mixture of surrogate SB2 and SB3 and SB6 with no added $\mathrm{Hf}(\mathrm{SBX}-0)$ and with $\mathrm{Hf}$ added to represent $1 \mathrm{wt} \% \mathrm{Pu}$ in glass on a equal molar basis (SBX-1).

Figure 4. XRD patterns of (a) surrogate SB6 with 0 wt \% Hf and (b) surrogate SB6 with $\mathrm{Hf}$ on an equivalent molar basis to $1 \mathrm{wt} \% \mathrm{Pu}$ in glass.

Figure 5. SEM/EDS mapping of $\mathrm{HfO}_{2}$ distribution within glass "crucible-form" for SB6 with $\mathrm{Hf}$ to represent $1 \mathrm{wt} \% \mathrm{Pu}$ on a molar basis that underwent minimal mixing. Figure depicts "crucible-form" section with scans from top to bottom of crucible... 19

Figure 6. SEM/EDS mapping of $\mathrm{HfO}_{2}$ distribution within glass "crucible-form" for SB6 with $\mathrm{Hf}$ to represent $1 \mathrm{wt} \% \mathrm{Pu}$ on a molar basis under well-mixed conditions. Figure depicts "crucible-form" section with scans from top to bottom of crucible. 20

Figure 7. SEM/EDS line scans of $\mathrm{HfO}_{2}$ distribution within glass "crucible-form" for SB6 with $\mathrm{Hf}$ to represent $1 \mathrm{wt} \% \mathrm{Pu}$ on a molar basis under well-mixed conditions. Figure depicts "crucible-form" section with line scans in specific regions. 21

Figure 8. XRD pattern of actual SB6 glass with $1 \mathrm{wt} \% \mathrm{Pu}$ in the glass. 23

Figure 9. X-ray diffraction patterns of (a) surrogate SB6 with 1 wt \% $\mathrm{Pu}$ - minimal mixing conditions and (b) surrogate SB6 with $1 \mathrm{wt} \% \mathrm{Pu}$ - well-mixed conditions. 24

Figure 10. SEM/EDS data for actual SB6 glass with $1 \mathrm{wt} \% \mathrm{Pu}-$ (a) low magnification micrograph of fines, (b) higher magnification micrograph of glass shard, (c) EDS spectrum of area defined by the box in (b).

Figure 11. SEM/EDS data for surrogate SB6 glass with $1 \mathrm{wt} \% \mathrm{Pu}$ prepared with minimal mixing. Undissolved $\mathrm{PuO}_{2}$ is evident in micrograph (a) and in EDS spectra (c).

Figure 12. SEM/EDS data for surrogate SB6 glass with 1 wt $\% \mathrm{Pu}$ prepared under wellmixed conditions. Only spinel (trevorite) crystals were eveident in the glass (b) and (c).

Figure 13. EDS spectra of surrogate SB6 glass with $1 \mathrm{wt} \% \mathrm{Pu}$ prepared under wellmixed (Wiggle Bug) conditions and minimally-mixed (Hand mixed) conditions. Relative peak intensities provide an indication of concentration of $\mathrm{Pu}$ in the glass. . 28 


\section{LIST OF ABBREVIATIONS}

$\begin{array}{ll}\text { ARM } & \text { Accepted Reference Material } \\ \text { ASTM } & \text { American Society for Testing and Materials } \\ \text { ATS } & \text { Alkali Tin Silicate } \\ \text { DWPF } & \text { Defense Waste Processing Facility } \\ \text { EA } & \text { Environmental Assement } \\ \text { EMPA } & \text { Electron Microprobe Analysis } \\ \text { EXAFS } & \text { X-ray Absorption Fine Structure } \\ \text { HLW } & \text { High Level Waste } \\ \text { ICP-AES } & \text { Inductively Coupled Plasma-Atomic Emission Spectroscopy } \\ \text { ICP-MS } & \text { Inductively Coupled Plasma-Mass Spectroscopy } \\ \text { IR } & \text { Infrared } \\ \text { LaBS } & \text { Lanthanide Borosilicate } \\ \text { PCT } & \text { Product Consistency Test } \\ \text { PF } & \text { Peroxide Fusion digestion } \\ \text { SB6 } & \text { Sludge Batch 6 } \\ \text { SME } & \text { Slurry Mix Evaporator } \\ \text { SEM/EDS } & \text { Scanning Electron Microscopy coupled with Energy Dispersive } \\ \text { SRNL } & \text { Spectroscopy } \\ \text { VHT } & \text { Savannah River National Laboratory } \\ \text { WAPS } & \text { Vapor Hydration Test } \\ \text { XANES } & \text { Waste Acceptance Product Specification } \\ \text { XPS } & \text { X-ray Absorption Near Edge Structure } \\ \text { XRD } & \text { X-ray Diffraction } \\ & \end{array}$




\subsection{Introduction}

The disposition of excess weapons-useable plutonium is an ongoing concern. Glass waste forms have been considered as suitable immobilization matrices for long-term $\mathrm{Pu}$ disposal. A disposition approach that involves dissolving the Pu materials in H-Area and sending through the SRS high-level waste system to incorporate the $\mathrm{Pu}$ in a high level waste (HLW) alkali borosilicate glass is now being considered.

In DWPF glasses processed to date, the concentration of plutonium and other fissile materials was low (typically on the order of $0.01 \mathrm{wt} \%$ ). The current upper limit for fissile material in a DWPF canister based on the Yucca Mountain License Application is $897 \mathrm{~g} / \mathrm{m}^{3}$ (about $0.02 \mathrm{wt} \%$ ). The behavior of plutonium in the glass at these levels has been determined not to impact processing, criticality safety or glass performance. If $\mathrm{Pu}$ levels in the glass are increased to significantly higher levels, an understanding of the behavior of $\mathrm{Pu}$ during processing, in the produced glass, and during long-term glass degradation is needed.

The relative solubility can be dependent on factors affecting the local structure of $\mathrm{Pu}$ in the glass (e.g. coordination with respect to oxygen, charge valence, ionic radius, etc.). Furthermore, the high relative density of $\mathrm{PuO}_{2}$ is a consideration with respect to stratification within the glass during melting and the potential for settling out in a melter assuming $\mathrm{Pu}$ solubility or retention limits are exceeded. Inhomogeneity of plutonium within the glass could lead to unfavorable crystallization or criticality concerns due to concentration of fissile material within the melter or within the canistered waste form if Pu solubility limits are exceeded.

An understanding of glass corrosion behavior is needed to support performance assessment efforts associated with repository disposition. This includes understanding glass leaching under varying conditions such as solution $\mathrm{pH}$, temperature, leachate composition, etc. This translates to a need to predict radionuclide behavior either through bounding arguments based on dissolution of the glass network or through an understanding of the release behavior of the specific radionuclide. It may be necessary for a specific understanding of overall glass performance if significant Pu quantities (i.e. above current HLW glass concentrations) are to be contained in a glass slated for repository disposition. Moreover, since plutonium is a fissile material, understanding the release behavior of plutonium (e.g. colloid formation and release) may be needed to ensure criticality scenarios are precluded. In this study, the assessment of increased $\mathrm{Pu}$ concentrations in the glass on Product Consistency Test - Method A (PCT-A) response was evaluated. The PCT-A is the current benchmark test used for repository acceptance of a glass waste form and for qualification of new feed streams to DWPF. Future testing may be necessary for repository qualification to further evaluate the effect of increased $\mathrm{Pu}$ concentrations on glass corrosion performance and/or the fate of $\mathrm{Pu}$ leached from the glass, however, this testing is beyond the scope of the current study.

In this task, the behavior of $\mathrm{Pu}$ in a sludge batch 6 (SB6) reference glass was evaluated. $\mathrm{A} \mathrm{Pu}$ loading of $1 \mathrm{wt} \%$ in glass was studied (this loading translated to $\sim 18 \mathrm{~kg} \mathrm{Pu} /$ canister, or about 10X the current allowed limit per the Waste Acceptance Product Specifications and about 30X the current allowable concentration based on the fissile material concentration limit referenced in the Yucca Mountain Project License Application). Based on historical process throughput data, this level is considered to represent a reasonable upper bound for Pu loading based on the ability to provide $\mathrm{Pu}$ containing feed to the Defense Waste Processing Facility (DWPF). The task elements included evaluating the distribution of $\mathrm{Pu}$ in the glass (e.g. homogeneity), evaluating crystallization within the glass, evaluating select glass properties (with surrogates), and 
evaluating durability using the PCT-A. The behavior of $\mathrm{Pu}$ in the melter was evaluated using paper studies and corresponding analyses of DWPF melter pour samples.

\subsection{Literature Study}

A literature survey was performed to review previous studies involving incorporation of $\mathrm{Pu}$ in alkali borosilicate glasses. Areas assessed included solubility of $\mathrm{Pu}$ in glass, effects on glass durability, radiation effects, and effects on glass processing.

\subsection{Plutonium Solubility in Glass}

The relative solubility of $\mathrm{PuO}_{2}$ in glasses has been reported by several researchers. In this literature study, interpretation of this information was problematic because the compositions of the glasses varied widely as did the processing conditions used to fabricate the glasses. Additionally, the method used to determine solubility differed and was usually somewhat qualitative. In most cases, solubility was determined by visual examination of the glass (either with the unaided eye or using microscopy) and/or crystalline phase identification (or lack thereof) using x-ray diffraction (XRD). In only a few instances was the relative distribution of plutonium within the glass discussed as it relates to homogeneity of plutonium within the glass. Furthermore, all results were based on crucible-scale testing under primarily static conditions. In a few cases, means to homogenize the glass (e.g. by stirring) were utilized.

The results of a number of studies are discussed below. Appendix A contains the glass compositions from these studies. Some compositions are given with base glass composition and ranges of $\mathrm{PuO}_{2}$ because in these studies a range of plutonium concentrations was evaluated.

One of the most in depth investigations of plutonium solubility in alkali borosilicate glass was completed by French workers (Deschanels, 2007). The researchers studied the effects of temperature and redox conditions on the solubility of plutonium in a "complex" glass system (similar to the French R7T7 composition) and a "simple" glass system. The simple system removed the redox sensitive elements (such as Fe and Ce) from the glass to support study of the potential to reduce plutonium to increase solubility. The authors reported that molecular dynamic simulations and spectroscopy measurements showed that the complex and simple glass were structurally similar. The plutonium was added to the glass forming chemicals as a nitrate solution. It was determined that up to $2 \mathrm{wt} \% \mathrm{PuO}_{2}$ could be dissolved in the complex glass when melting at $1200{ }^{\circ} \mathrm{C}$ in air or argon. If melting was conducted at $1400{ }^{\circ} \mathrm{C}$, up to $3 \mathrm{wt} \% \mathrm{PuO}_{2}$ was incorporated into the complex glass. The researchers observed that up to $4 \mathrm{wt} \% \mathrm{PuO}_{2}$ could be dissolved in the simplified glass when $\mathrm{Si}_{3} \mathrm{~N}_{4}$ was added to the batch as a reducing agent to facilitate some reduction of $\mathrm{Pu}^{4+}$ to $\mathrm{Pu}^{3+}$. It is assumed that the melts were static as no mention of stirring or agitation was made. The authors also used electron microprobe analysis (EMPA) to determine the relative concentration of plutonium vs. depth in the crucible melts. The EMPA analyses indicated that the $\mathrm{PuO}_{2}$ concentration was relatively constant through the glass melt.

Plodinec evaluated $\mathrm{PuO}_{2}$ solubility in early Savannah River Site waste glasses (Plodinec, 1979). He reported that up to $4 \mathrm{wt} \% \mathrm{PuO}_{2}$ was soluble in a waste glass containing Frit 21 and a composite simulated calcined sludge at $25 \mathrm{wt} \%$ waste loading while up to $7 \mathrm{wt} \% \mathrm{PuO}_{2}$ was soluble in a waste glass containing Frit 411 and a composite simulated calcined sludge at $25 \mathrm{wt} \%$ waste loading. The report did not mention how $\mathrm{PuO}_{2}$ solubility was determined or whether the melts were agitated.

Bates and coworkers looked at plutonium oxide incorporation in DWPF blend glasses based on the Frit 202 composition (Bates, 1995) and the leaching behavior of these glasses. Glasses were 
prepared at concentrations of 2 wt $\% \mathrm{Pu}\left(2.27\right.$ wt $\left.\% \mathrm{PuO}_{2}\right)$ and 7 wt $\% \mathrm{Pu}\left(7.94\right.$ wt $\left.\% \mathrm{PuO}_{2}\right)$. A third glass was prepared with $2 \mathrm{wt} \% \mathrm{Pu}$ where Gd was added to the composition at an equivalent molar ratio to $\mathrm{Pu}$. The plutonium was added to the glass forming chemicals as a nitrate solution and glasses were melted at $1150{ }^{\circ} \mathrm{C}$ in air. No mention of agitation was made so it was assumed that melts were static. Analysis of glass samples following leach testing indicated that undissolved or recrystallized $\mathrm{PuO}_{2}$ was present in the $7 \mathrm{wt} \% \mathrm{Pu}$ glass, clearly indicating that the solubility for $\mathrm{Pu}$ in this glass system was exceeded. No evidence of undissolved or crystallized $\mathrm{PuO}_{2}$ was observed in the $2 \mathrm{wt} \% \mathrm{Pu}$ glasses.

As a follow-on to the above study, Bates, et al. developed an alkali tin silicate (ATS) glass in an effort to increase $\mathrm{Pu}$ solubility in the glass (Bates, 1996). The glass was fabricated at $1150{ }^{\circ} \mathrm{C}$ using a $\mathrm{Pu}$ nitrate solution to result in $10 \mathrm{wt} \% \mathrm{Pu}\left(11.34 \mathrm{wt} \% \mathrm{PuO}_{2}\right)$ in the glass. Again the melts were assumed to be static. Electron microscope analyses of the glass indicated that about 7 wt $\% \mathrm{Pu}\left(7.94 \mathrm{wt} \% \mathrm{PuO}_{2}\right)$ was dissolved in the glass with the remainder forming a $\mathrm{PuO}_{2}$ crystalline phase dispersed throughout the glass. Later work on the ATS system demonstrated that $5 \mathrm{wt} \% \mathrm{Pu}\left(5.67 \mathrm{wt} \% \mathrm{PuO}_{2}\right)$ could be dissolved in the glass with no evidence of undissolved or crystallized $\mathrm{PuO}_{2}$ as determined by electron microscopy (Mertz, 1998). Therefore, it was concluded that under these test conditions the solubility of Pu in the ATS glass was between 5 and $7 \mathrm{wt} \%$.

Bonniaud and coworkers evaluated plutonium concentrations up to about $3.3 \mathrm{wt} \% \mathrm{PuO}_{2}$ to study alpha radiation effects (Bonniaud, 1980). The borosilicate glasses were doped with either a mix of $\mathrm{Pu}$ isotopes or pure $\mathrm{Pu}-238$ to accelerate the dose to the glasses. The glasses were melted at $1150{ }^{\circ} \mathrm{C}$ in air but the $\mathrm{Pu}$ source was not specified. The melts were performed using a "pot vitrification technique" that was assumed to be static. Samples were poured in molds to form disks and blocks ( $2 \mathrm{~cm}$ diameter x $5 \mathrm{~cm}$ high and $8 \mathrm{~cm}$ diameter $\times 10 \mathrm{~cm}$ high). Undissolved $\mathrm{PuO}_{2}$ was observed in the glass by optical microscopy and confirmed by XRD.

Marples also doped borosilicate glass compositions with $\mathrm{Pu}-238$ to study radiation effects (Marples, 1996). Glasses were doped at $2.5 \mathrm{wt} \% \mathrm{PuO}_{2}$ and $5 \mathrm{wt} \% \mathrm{PuO}_{2}$. Experimental conditions for glass fabrication were not given. Visual examination and autoradiography showed that at both levels some of the $\mathrm{PuO}_{2}$ crystallized from the melt and formed small cubes in the glass.

Matzke and van Geel evaluated the solubility of $\mathrm{PuO}_{2}$ in a German HLW glass composition. The glasses were melted at $1150{ }^{\circ} \mathrm{C}$ initially in Pt crucibles followed by pulverizing the samples and melting again in graphite crucibles. Plutonium was added as $\mathrm{PuO}_{2}$ to a denitrited waste solution and glass forming chemicals. At $10 \mathrm{wt} \% \mathrm{PuO}_{2}$, segregation of $\mathrm{PuO}_{2}$ was obvious. Tests were repeated with $5 \mathrm{wt} \% \mathrm{PuO}_{2}$ with varying concentrations of $\mathrm{HLW}$ and neutron poison $\left(\mathrm{Gd}_{2} \mathrm{O}_{3}\right)$. A vitreous phase and $\mathrm{PuO}_{2}$ phase were also evident in all samples at this doping level. Microscopic chemical analysis indicated that between 1.2 and $4.6 \mathrm{wt} \% \mathrm{PuO}_{2}$ was dissolved in the vitreous phase depending on the level of HLW oxides in the glass. The lowest solubility $\left(1.2 \mathrm{wt} \% \mathrm{PuO}_{2}\right)$ was in a sample containing $20 \mathrm{wt} \%$ waste oxides and $10 \mathrm{wt} \% \mathrm{Gd}_{2} \mathrm{O}_{3}$.

Other glass systems have been evaluated to immobilize high concentrations of $\mathrm{PuO}_{2}$, most notably the lanthanide borosilicate (LaBS) compositions. Vienna, et al. performed $\mathrm{PuO}_{2}$ solubility experiments to determine the maximum concentration of $\mathrm{PuO}_{2}$ that could be dissolved in the LaBS glass system (Vienna, 1996). It was determined that $13.4 \mathrm{wt} \% \mathrm{PuO}_{2}$ (amount added to the batch) could be dissolved in a LaBS composition when melted at $1500{ }^{\circ} \mathrm{C}$ in air at the crucible-scale using $\mathrm{PuO}_{2}$ as the $\mathrm{Pu}$ source. In these tests, intermittent manual stirring of the melt was performed to enhance homogenization. Microscopic analysis was performed on the crucible 
melts, and although it was determined that complete homogenization was achieved at $13.4 \mathrm{wt} \%$ $\mathrm{PuO}_{2}$, there was noticeable stratification within the melt (with $\mathrm{PuO}_{2}$ enrichment at the bottom of the crucible). In the enriched areas, approximately $16 \mathrm{wt} \% \mathrm{PuO}_{2}$ was observed to be dissolved in the glass.

Marra and co-workers have continued development of LaBS glasses and studied $\mathrm{PuO}_{2}$ dissolution in the glass (Marra, 2006). The LaBS Frit X composition was melted at $1500{ }^{\circ} \mathrm{C}$ in Pt crucibles under static conditions using $\mathrm{PuO}_{2}$ as the $\mathrm{Pu}$ source. LaBS frit and $\mathrm{PuO}_{2}$ were manually combined and mixed by shaking the bottle containing the mix. The $\mathrm{PuO}_{2}$ concentration in the glass was targeted at $9.5 \mathrm{wt} \%$. Some evidence of $\mathrm{PuO}_{2}$ crystallization was evident in the glasses. Furthermore, heat treating resulted in an increase in crystallization of a $\mathrm{PuO}_{2}-\mathrm{HfO}_{2}$ solid solution phase in the glass.

In FY09, Marra, et al. fabricated and analyzed Pu LaBS glasses with the Frit A composition (the same composition studied by Vienna, et al.) as part of a Laboratory Directed Research and Development Program (Marra, 2009). Glasses were prepared using Frit $\mathrm{A}$ and $\mathrm{PuO}_{2}$ at 5 wt \% and $9.5 \mathrm{wt} \% \mathrm{PuO}_{2}$ levels. The mixture of frit and $\mathrm{PuO}_{2}$ was mixed using a Wig-L-Bug® and then melted at $1500{ }^{\circ} \mathrm{C}$ under static conditions in an open $\mathrm{Pt} / \mathrm{Rh}$ crucible. After melting and direct quenching by immediate placement of the crucible in water, the glass was removed from the crucible, crushed again using the Wig-L-Bug®, and then remelted and quenched under the same conditions as the initial melt. The glasses were examined using XRD and scanning electron microscopy coupled with energy dispersive spectroscopy (SEM/EDS). At $5 \mathrm{wt} \% \mathrm{PuO}_{2}$, there was no evidence of crystallization within the glass from the highest magnification SEM scans. Energy dispersive spectroscopy spectra of various raster-sections of the amorphous glass indicated plutonium was incorporated into the glass matrix with the other cations. At $9.5 \mathrm{wt} \%$ $\mathrm{PuO}_{2}$ there was minor evidence of crystallization that appeared to nucleate at the Pt crucible interface.

In this same LDRD study, Marra, et al. evaluated $\mathrm{PuO}_{2}$ inclusion in an alkali borosilicate composition. The glass batches were prepared similarly to the LaBS Frit A glasses but the glasses were melted at $1150{ }^{\circ} \mathrm{C}$ in $\mathrm{Pt} / \mathrm{Au}$ open crucibles. These glasses were also quenched in water. Plutonium oxide was added at $0.5 \mathrm{wt} \%$ and $2 \mathrm{wt} \%$ in the glass. X-ray diffraction and $\mathrm{SEM} / \mathrm{EDS}$ analyses indicated that the $\mathrm{PuO}_{2}$ was completely dissolved in the glass. Elemental spot analyses using EDS further indicated that the $\mathrm{PuO}_{2}$ was uniformly dispersed within the glass.

Matyunin and coworkers evaluated $\mathrm{PuO}_{2}$ solubility in phosphate glasses (Matyunin, 1996). In this testing, the authors evaluated $\mathrm{PuO}_{2}$ levels of 0.8 and $3.4 \mathrm{wt} \%$. The glasses were melted in crucibles at $1000{ }^{\circ} \mathrm{C}$ for varying times ranging from 8 to 200 hours. The distribution of $\mathrm{PuO}_{2}$ in samples melted for 8 hours was found to be relatively uniform using gamma scanning. With increasing melting time, the concentration of $\mathrm{PuO}_{2}$ in the bottom of the crucible increased. XRD analyses confirmed the presence of $\mathrm{PuO}_{2}$ material in the bottom of the crucibles.

These literature references provided data for a wide range of $\mathrm{Pu}$ concentrations in glass where $\mathrm{Pu}$ was found to be soluble and insoluble. From these studies, it was reasonable to conclude that $\mathrm{Pu}$ would be soluble in DWPF-type borosilicate glass at $1 \mathrm{wt} \%$.

\subsection{Local Environment of Pu in Glass}

The manner in which an ion is accommodated in a glass network can influence its relative solubility and behavior within the glass (e.g. release due to aqueous corrosion, crystallization tendency, etc.). A cation can assume three structural roles within a glass: network former, 
network modifier or intermediate (Kingery, 1976). A network former acts to promote the formation of polyhedra within the glass, thus, providing short range order in the glass. A network modifier acts to modify the network structure and provide additional oxygen ions to accommodate other cations through charge neutrality. Intermediates are of lower coordination than network formers and may sometimes act as network formers or as network modifiers.

Several factors influence the local atomic environment of cations within a glass. These include: the valence state and the stability of a particular valence state, the reduction-oxidation (redox) potential of the melt, the radius of the cation and the coordination afforded by the glass structure. Muller and Weber discussed these factors with respect to plutonium within a glass structure based on theoretical arguments (Muller, 2001). They indicated that plutonium acts as an intermediate within the glass structure. They also concluded that in typical borosilicate glasses plutonium was in the +4 state and had a generally high coordination number of 6-8. They also noted that under extreme reducing conditions, plutonium could be reduced to +3 in the glass.

Deschanels, et al. used extended x-ray absorption fine structure (EXAFS) spectroscopy and magic-angle spinning nuclear magnetic resonance spectroscopy to examine the structure of plutonium in a borosilicate glass in the oxidized $(+4)$ state and reduced $(+3)$ state (Deschanels, 2007). The analyses showed that $\mathrm{Pu}^{4+}$ acted like an intermediate and promoted network forming in the glass while $\mathrm{Pu}^{3+}$, while still an intermediate, acted like a network modifier. The EXAFS data indicated that the coordination number for plutonium in the glass was approximately 8 .

Hess, et al. used EXAFS and x-ray absorption near edge structure (XANES) spectroscopy to evaluate the structure of aged Pu-doped glass as part of an irradiation damage study (Hess, 1998a; Hess, 1998b). The glass studied was a U.S. defense waste-type borosilicate glass with $1 \mathrm{wt} \%$ $\mathrm{PuO}_{2}$ with varying $\mathrm{Pu}$ isotopic ratios to vary the accumulated alpha dose in the glass. The authors did not provide results regarding $\mathrm{PuO}_{2}$ solubility in the glass. The XANES data indicated that the $\mathrm{Pu}$ was in the +4 state within the glass. The average coordination number ranged from $6.0-6.7$.

Karraker evaluated the valence of actinides in a simplified borosilicate glass using optical and Mössbauer spectroscopy (Karraker, 1982). He evaluated a glass with approximately $0.5 \mathrm{wt} \%$ $\mathrm{PuO}_{2}$ in the glass and evaluated melts in air and with added graphite powder as a reductant. No discussion on $\mathrm{PuO}_{2}$ solubility in the glass was provided. Under all conditions, he concluded that $\mathrm{Pu}$ was in the +4 state in the glass.

Stefanovsky and coworkers examined a Pu-bearing LaBS Frit X glass containing 9.5 wt $\% \mathrm{PuO}_{2}$ (Stefanovsky, 2007, Maslakov, 2009). In these studies, EXAFS, XANES, x-ray photoelectron spectroscopy (XPS) and infrared (IR) spectroscopy were used to determine the valence state and local structure of the glass. XANES analyses indicated that the Pu oxidation state was primarily +4 . The average coordination number for $\mathrm{Pu}$ was determined to be about 6.1. The authors reported that there was some undissolved $\mathrm{PuO}_{2}$ in these glasses.

The data from these studies consistently showed that $\mathrm{Pu}$ existed in the glass in a +4 state (unless the glass was prepared under extreme reducing conditions). Generally, the coordination number of $\mathrm{Pu}$ in the glass was between 6 and 7.

\subsection{Glass Durability}

The durability of borosilicate glasses has been studied extensively. However, since $\mathrm{PuO}_{2}$ is a very minor constituent of typical HLW glasses, the leaching behavior of plutonium in these 
glasses has not been widely studied. A few studies have been performed including some that have attempted to evaluate the release behavior of plutonium from the glass.

Vernaz and Godon evaluated the leaching of actinides from French waste glasses (Vernaz, 1992). They studied the $\mathrm{R} 7 \mathrm{~T} 7$ reference glass with $0.85 \mathrm{wt} \% \mathrm{PuO}_{2}$ loading and the $\mathrm{SON} 58$ reference glass with $2.8 \mathrm{wt} \% \mathrm{PuO}_{2}$. There was no mention of solubility of $\mathrm{PuO}_{2}$ in the glasses. Testing conducted on the R7T7 and SON 58 glasses at room temperature where solution renewal was performed on a daily basis showed that initially the dissolution rate of $\mathrm{Pu}$ into solution was the same as the glass matrix elements (i.e. congruent dissolution). However, as corrosion progressed the dissolution rate of $\mathrm{Pu}$ into solution was significantly lower as amorphous gel layers formed on the glass surface and retained the $\mathrm{Pu}$. The fraction of $\mathrm{Pu}$ retained in the layer increased with temperature and as the solution renewal became less frequent. The temperature effect was validated in Soxhlet experiments on the R7T7 glass conducted at $100{ }^{\circ} \mathrm{C}$ with continuing flowing water. After 28 days, the $\mathrm{Pu}$ retention factor (normalized boron release/normalized $\mathrm{Pu}$ release) was 412 . Static leach tests were conducted on the R7T7 glass at $50{ }^{\circ} \mathrm{C}$ and $90{ }^{\circ} \mathrm{C}$ with a leachate surface area to glass volume ratio $(\mathrm{S} / \mathrm{V})$ of $50 \mathrm{~m}^{-1}$. After one year of leaching, the $\mathrm{Pu}$ concentrations in solution were similar for glasses exposed at both temperatures. Ultrafiltration of the leachate solutions showed that approximately $80 \%$ of the $\mathrm{Pu}$ in solution was in the form of colloids or particles. The Pu retention factor (normalized boron release/normalized Pu release) ranged from 24-50. Experiments were also conducted in the presence of other materials such as sand, granite, bentonite clay, smectite, illite, Boom clay and salt. As was seen in previous nonradioactive testing, glass alteration was slow in the presence of sand, granite and bentonite. Alteration was severe in the presence of smectite, illite, and Boom Clay, while the alteration was intermediate in salt. The retention of $\mathrm{Pu}$ in the gel layer varied in the presence of smectite. When the glass was in direct contact with smectite, the retention factor for Pu in the glass was only 6 . In contrast, when smectite was not in contact with the glass (smectite at the bottom of the leach vessel below the suspended coupon), the retention factor was about 100. It was noted that the actual $\mathrm{Pu}$ in solution was very low in all experiments since the sorption factors of the external materials for $\mathrm{Pu}$ were very high.

Bates, et al. compared the leach response of a reference DWPF glass with the typical $0.01 \mathrm{wt} \%$ $\mathrm{Pu}$ to glasses of the same composition doped with 2 and $7 \mathrm{wt} \% \mathrm{Pu}$ (Bates, 1995). In one glass with $2 \mathrm{wt} \% \mathrm{Pu}, \mathrm{Gd}$ was added in an equal molar amount to the $\mathrm{Pu}$ concentration. The glasses were tested using the Product Consistency Test - Method B (PCT-B) with a surface to volume ratio (S/V) of 20,000 $\mathrm{m}^{-1}$ and using the Vapor Hydration Test (VHT). The VHT is an accelerated leach test performed on monolithic samples at elevated temperatures in the presence of water vapor. As expected, the dissolution rates for all samples decreased with time as the solution became silica saturated in testing through 98 days. The relative release of B (as an indicator of glass matrix dissolution) was similar for all the glasses. The Pu released from the glass took the form of clay colloids in solution. The normalized release of $\mathrm{Pu}$ was lower than the $\mathrm{B}$ release and decreased with time as the $\mathrm{Pu}$ in solution in the form of colloids reprecipitated on the glass surface. Gadolinium release was similar to $\mathrm{Pu}$ release in that it remained incorporated in the clay phase with $\mathrm{Pu}$. In the $\mathrm{VHT}$, the glass with a concentration of $7 \mathrm{wt} \% \mathrm{Pu}$ reacted the most rapidly and included noticeable $\mathrm{PuO}_{2}$ crystalline forms in the altered layer as a result of insolubility during the glass fabrication process. The reference glass with $0.01 \mathrm{wt} \% \mathrm{Pu}$ and the glass with 2 wt $\% \mathrm{Pu}$ reacted similarly to each other. This could imply that the behavior of $\mathrm{Pu}$ in an alkali borosilicate would be similar from $0.01 \mathrm{wt} \%$ to $2 \mathrm{wt} \% \mathrm{Pu}$ in a defense waste-type alkali borosilicate glass. It was also observed that $\mathrm{Gd}$ behaved similarly to $\mathrm{Pu}$ in the VHT.

Bates and coworkers provided longer duration results for the above mentioned PCT-B tests with durations through 215 days (Bates, 1996). After 215 days, the $2 \mathrm{wt} \% \mathrm{Pu}$ and $7 \mathrm{wt} \% \mathrm{Pu}$ glasses 
still showed decreasing corrosion rates as evidenced by the B release rate. The $2 \mathrm{wt} \% \mathrm{Pu}$ glass with $\mathrm{Gd}$ showed a dramatic increase in dissolution rate after 215 days as measured by B release. However, the $\mathrm{Pu}$ (and $\mathrm{Gd}$ ) normalized releases for all glasses remained in the same range for all times. In this work, Bates et al. also reported on testing with the ATS glass with $10 \mathrm{wt} \% \mathrm{Pu}$ added (as previously discussed only about $7 \mathrm{wt} \% \mathrm{Pu}$ was dissolved in the glass). The PCT-B with a S/V of $20,000 \mathrm{~m}^{-1}$ and the VHT were performed on this glass. The B release rate for the ATS glass was slightly higher than the DWPF reference glasses. In contrast, the Pu release for ATS glass was slightly lower than the DWPF reference glasses. Additionally, the Gd release was slightly higher than the Pu release. The VHT showed that only a very thin alteration layer formed on the ATS glass after 56 days compared to the relatively thick clay alteration layer that formed on the DWPF reference glasses. Transmission electron microscopy indicated that the thin layer was Sn-Ti-Fe-Al-Si clay containing both Pu and Gd.

Bonniaud, et al. performed static leach testing using solution renewal at 23,50 and $70{ }^{\circ} \mathrm{C}$ (Bonniaud, 1980). The $\mathrm{S} / \mathrm{V}$ for the tests was not given. The $\mathrm{Pu}$ leach rates appeared to be relatively insensitive to temperature at $\mathrm{pH}=7-8$. The leachate was recovered and filtered using a series of microfilters. It was concluded that more than $50 \%$ of the $\mathrm{Pu}$ in solution was in the form of colloidal compounds greater than $50 \mathrm{~nm}$. A leach test performed in a $\mathrm{pH}=1$ buffered solution at room temperature indicated that $\mathrm{Pu}$ release rates increased by 100 fold compared to $\mathrm{pH}=7-8$ conditions.

Crawford and coworkers performed leach tests on a LaBS Frit B glass using the PCT-A and PCT$\mathrm{B}$ procedures at $90{ }^{\circ} \mathrm{C}$ with varying $\mathrm{S} / \mathrm{V}$ ratios and time durations (Crawford, 2007). The glass was fabricated with $9.5 \mathrm{wt} \% \mathrm{PuO}_{2}$; however, SEM and XRD analyses indicated that there was some crystalline $\mathrm{PuO}_{2}$ in the glass. The PCT-A test showed that the B release for the LaBS glass was about 640 times lower than that of the benchmark Environmental Assessment (EA) glass. The PCT-B results for tests conducted at an S/V of $21,000 \mathrm{~m}^{-1}$ for $7,14,28$ and 56 days were comparable to the PCT-A results indicating that the LaBS glass was very durable. Leachate solutions were filtered using a $0.45 \mu \mathrm{m}$ filter and then ultrafiltered to look for the presence of colloids. No difference was seen between the filtered solutions indicating colloid formation did not occur.

Wellman et al. studied the elemental dissolution of plutonium-bearing borosilicate glasses (Wellman et al., 2005). Single-pass flow-through tests were conducted to study the effects of self-radiation damage from alpha decay on dissolution kinetics of three radiation-aged (up to 20 years) Pu-bearing $\left(1 \mathrm{wt} \% \mathrm{PuO}_{2}\right)$ borosilicate glasses over a $\mathrm{pH}$ interval of 9-12 at $80-88{ }^{\circ} \mathrm{C}$. The chemical compositions of the glasses were identical except for the ${ }^{239} \mathrm{Pu} /{ }^{238} \mathrm{Pu}$ isotopic ratio, which was varied to yield accumulated doses of $1.3 \times 10^{16}, 2.9 \times 10^{17}$, and $2.6 \times 10^{18} \alpha$-decays $/ \mathrm{g}$ at the time of testing. Conclusions from these leaching studies were that release rates of Pu were $10^{2}$ - to $10^{5}$-fold slower compared to all other elements and were not affected by isotopic composition, self-radiation damage sustained by the glass, or $\mathrm{pH}$. These data demonstrate that self-radiation damage did not affect glass dissolution rates, despite exposure to internal radiation doses for $>20$ years. This study was also important in that it discussed the advantages of using flow-testing over static leach tests to minimize the effects of solution saturation and build-up of radiolytic products in the leachate solution. The authors stated that "because the solution in the reaction vessel was continuously replenished, radiolysis products and dissolved glass components were not allowed to build up and the solution $\mathrm{pH}$ was maintained at constant values." Thus, radiolysis effects, as observed in earlier static tests were minimized. The earlier static tests referred to have been reviewed by various review articles on radiation effects on glass dissolution from the 1990s (Weber et al., 1997, and Wronkiewicz, 1994). 
The results of these cited studies indicated that incorporation of $\mathrm{Pu}$ in the glass appeared to have no impact on the overall durability of the glass. The studies that specifically evaluated Pu release mechanisms showed that $\mathrm{Pu}$ release was low but that $\mathrm{Pu}$ colloids were formed in solution. This release behavior may require further study when considering repository qualification of glasses with high Pu concentrations.

\subsection{Radiation Effects}

There has been a significant amount of testing to evaluate the response of borosilicate glasses to $\alpha$, $\beta$, and $\gamma$ irradiation over the past several decades. The text edited by Lutze and Ewing from 1988 contained a summary of radiation effects and alpha-decay damage on nuclear waste forms including both glasses and ceramics that were known up through the late 1980s (Lutze and Ewing, 1988). A more recent compilation text by French authors Caurant et al. also reviewed and summarized studies on glasses for the immobilization of highly radioactive solutions including those derived from reprocessing of high-level waste (Caurant et al., 2009). In general, these studies have shown that borosilicate glasses are resistant to radiation damage. Alpha recoil can lead to atom displacement in a crystalline or glass structure and is a specific concern for high $\mathrm{Pu}$ content waste forms if these displacements result in changes in the waste form structure that affect performance. There have been several studies that have looked at $\alpha$ radiation damage in borosilicate glasses as it relates to elevated $\mathrm{Pu}$ contents in the glass. These studies have been performed using high $\alpha$-emitting actinides (e.g $\mathrm{Pu}-238$ and/or $\mathrm{Cm}$-244) to accelerate radiation doses in the glasses.

For instance, Figure 1 below from the comprehensive review article on radiation effects in glasses used for immobilization of high-level waste and plutonium disposition (Weber et al., 1997) showed that the cumulative dose in alpha-decays/g can approach levels of $\sim 1 \times 10^{19} \alpha / \mathrm{g}$ after 10,000 years of storage for a glass containing $\sim 5 \mathrm{wt} \% \mathrm{Pu}-239$. Thus by using the high $\alpha$-emitting actinides Pu-238 and/or Cm-244 as glass dopants to attain damage levels on the order of $10^{18} \mathrm{\alpha} / \mathrm{g}$ within years of glass fabrication, researchers have been able to "simulate" the radiation damage expected in glasses after thousands of years.

Matzke and van Geel looked at a German HLW borosilicate glass doped with $1.5 \mathrm{wt} \% \mathrm{Cm}-244$ (Matzke, 1996). The glass saw a cumulative dose of about $2 \times 10^{18} \alpha / g$ which the authors translated to a dose that a glass containing $7 \mathrm{wt} \% \mathrm{Pu}-239$ would see in approximately 1000 years. The authors measured the leach response (static test in deioinized water for 14 days at $150 \mathrm{C}$, $\mathrm{S} / \mathrm{V}$ was not provided), mechanical property response and He behavior within the glass after selfirradiation of the glass. There was no significant change in the leach behavior of the glass after irradiation (actually leach rates appeared to be lower after irradiation). The volume change in the glass following irradiation was less than $0.5 \%$. The hardness and Young's Modulus were observed to decrease after irradiation while the fracture toughness increased about $100 \%$ after irradiation. There was some He build-up within the glass. Upon direct heating of the glass at $500{ }^{\circ} \mathrm{C}$, the glass volume increased about $100 \%$ due to what was described as foaming behavior. 


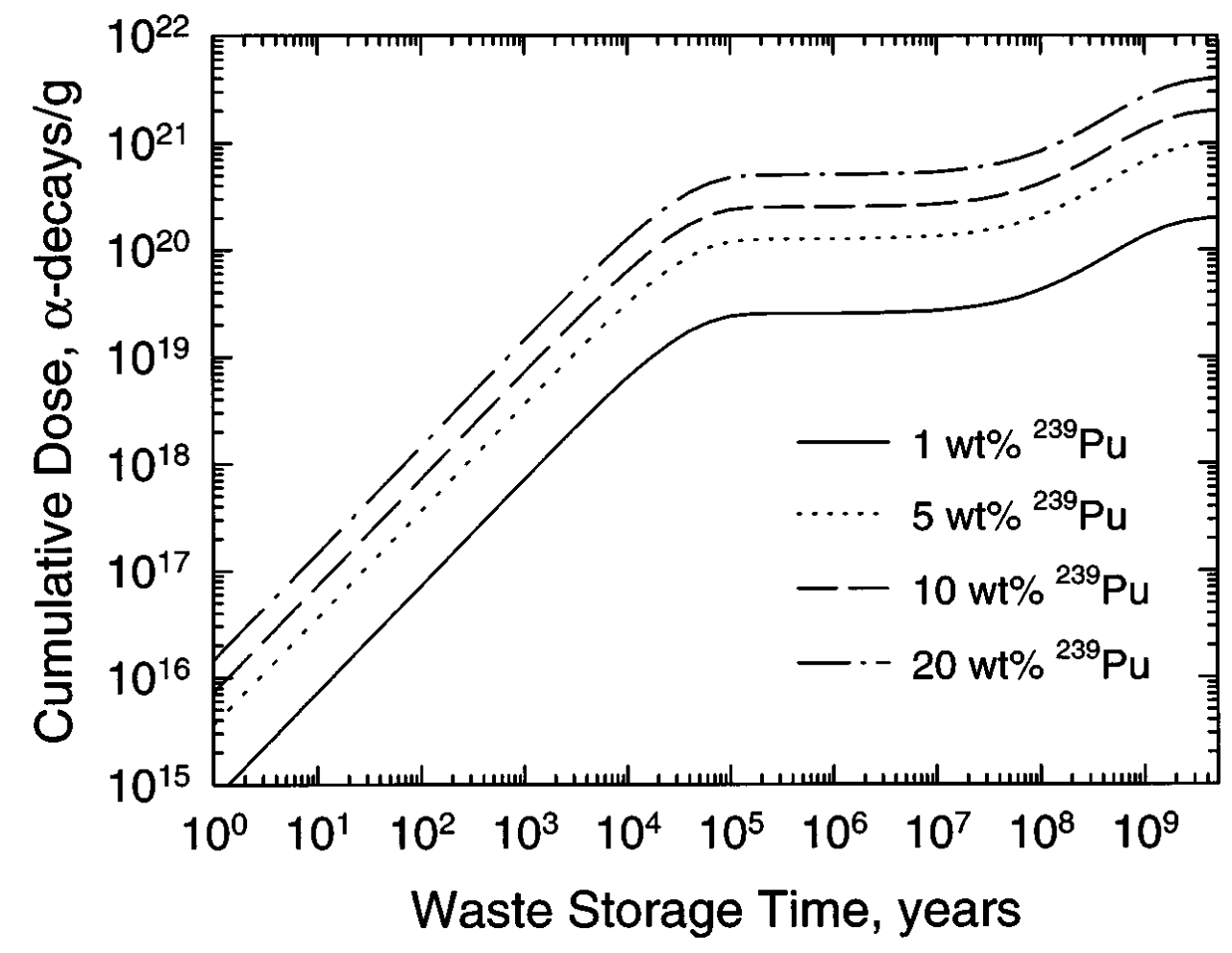

Figure 1. Cumulative $\alpha$-decay dose as a function of plutonium loading and waste storage time - from Weber et al., 1997.

Furuya and coworkers evaluated the irradiation response of a borosilicate glass doped with about 1 wt $\% \mathrm{PuO}_{2}$ (isotopic distribution including Pu-238) and about 3 wt \% Cm-244 (Furuya, 1996). The cumulative dose was about $5 \times 10^{18} \alpha / \mathrm{g}$. The author evaluated changes in microstructure and mechanical properties and also evaluated He build-up and release upon annealing. The change in volume was +0.4 to $+0.6 \%$ after irradiation. Self-irradiation of the glass at this level resulted in decreases in hardness and Young's modulus and an increase in fracture toughness. The helium release behavior was evaluated at several temperatures. It was concluded that the release of $\mathrm{He}$ was not only a simple diffusion process but also involved trapping of $\mathrm{He}$ in bubbles.

Deschanels, et al. looked at a borosilicate waste glass composition doped with varying concentrations of Cm-244 to obtain a maximum accumulated $\alpha$ dose to the glass of $4 \times 10^{18} \alpha / \mathrm{g}$ (Deschanels, 2007). The authors evaluated physical and mechanical properties and initial glass alteration rate after irradiation. They concluded that a maximum increase in volume of $0.5 \%$ occurred after a dose of $2 \times 10^{18} \alpha / \mathrm{g}$. The authors also observed that the decrease in hardness reached a maximum of about $35 \%$ after a dose of about $1.5 \times 10^{18} \alpha / \mathrm{g}$. Finally, they concluded that within the uncertainty of the measurements, irradiation up to these levels did not change the initial alteration rate of the glass.

Peuget and coworkers doped the French reference R7T7 glass with Pu-238, Am-241 and Np-237 at oxide levels of $0.85 \mathrm{wt} \%$ in the glass and measured the leach response of the glasses (Peuget, 2007). The testing reached alpha decay dose levels up to $4 \times 10^{18} \alpha / \mathrm{g}$. The results indicated that neither the alpha activity (due to different alpha emitters) nor the decay dose caused any change in the leach behavior of the glass. 
An earlier, related study by Peuget and coworkers also doped the French reference R7T7 borosilicate glass with $0.04,0.4,1.2$ and $3.25 \mathrm{wt} \%\left({ }^{244} \mathrm{CmO}_{2}\right)$ and varying levels of ${ }^{240} \mathrm{PuO}_{2}$ in the range of 0.12 to $0.74 \mathrm{wt} \%$ (Peuget et al., 2006). Although this study focused on the radiation damage primarily from the $\mathrm{Cm}-244$ loadings to give up to $3 \times 10^{18} \alpha / \mathrm{g}$ (i.e., not from $\mathrm{Pu}-238$ alpha decay), it does give similar conclusions as the 2007 work above. That is, "No significant effect on the initial alteration rate was detected which means that the chemical reactivity of the glass with pure water is not affected by such levels of alpha doses up to 2 x $10^{18} \alpha / \mathrm{g}$."

Hess, et al. used EXAFS to study the structure of $\alpha$-irradiated borosilicate glasses (Hess, 1998a). The glasses contained varying concentrations of $\mathrm{Pu}$ isotopes to provide a cumulative dose ranging from $8.8 \times 10^{15}$ to $1.9 \times 10^{18} \mathrm{\alpha} / \mathrm{g}$. The results indicated that the response was not the same for all elements within glass. Cations with relatively low coordination in the glass such as $\mathrm{Fe}$ and $\mathrm{Si}$ were the most resistant to displacement. It was theorized that these cations had relatively short bond lengths with oxygen and were tightly bonded, thus, resisting radiation damage. The studies did indicate, however, that some change in the bond angles for the Si-O-Si bonds may have occurred due to $\alpha$-irradiation. Larger cations such as the alkalis, alkaline earths and actinides have higher coordination numbers and longer cation - oxygen bond lengths. These cations tended to be more sensitive to displacement due to alpha recoil events.

The cited studies that evaluated the effect of alpha irradiation due to incorporation of $\mathrm{Pu}$ in the glass consistently indicated that alpha irradiation had no impact on glass durability. These studies did note that a small volume increase and He retention resulted from alpha irradiation.

\subsection{Glass Processing}

The effect of elevated $\mathrm{Pu}$ concentrations on glass processing has been evaluated qualitatively but it does not appear that any testing at a scale to reasonably mimic production-scale operations has been conducted. Belgian, French, and U.S. researchers have performed some analyses with respect to processing $\mathrm{Pu}$ in their production facilities.

Demonie and Cuyvers concluded that vitrification of a mixture of HLW and Pu from weapons dismantling was feasible in a facility like the Pamela plant in Belgium (Demoine, 1996). The authors evaluated criticality aspects and concluded that the use of increased amounts of B for criticality control and limiting the $\mathrm{Pu}-239$ concentration to below $6 \mathrm{~g} / \mathrm{L}$ would preclude criticality in the Pamela process. The authors also considered He build-up and release from the canisters and suggested that the container lid could be fitted with a carbon filter to avoid pressure build-up due to helium. They also indicated that an increase in analytical control, verification and security would be required to handle the fissile plutonium.

Jouan evaluated the disposition of $\mathrm{Pu}$ using vitrification processes (Jouan, 1996). It was concluded that a separate vitrification process without fission products would be simplest and least costly. However, vitrification of $\mathrm{Pu}$ with fission products using either a dry method (e.g. French process) or a liquid feed method (e.g. DWPF) was also deemed to be feasible with appropriate safety measures. In a dry process, it was thought that criticality control would be more straightforward. In contrast, a liquid feed process would allow for better metering of feed solutions and better inventory control.

Wicks, et al. discussed several options to disposition excess weapons-useable plutonium (Wicks, 1996). These included a "direct vitrification" option where Pu is melted directly with Cs-137 or HLW and a "staged vitrification" approach where a Pu-only glass is first vitrified and then either added as a frit in a HLW vitrification process or safeguarded by placing cans of the Pu glass in 
HLW canisters (i.e. can-in-canister approach). The authors indicated that the advantage of the direct option was that it represented a higher degree of proliferation resistance. The staged vitrification option was thought to be more straightforward from a $\mathrm{Pu}$ glass processing perspective. The advantages of leveraging HLW glass technology development and waste form qualification efforts were also discussed.

The literature review provided useful information regarding the solubility of $\mathrm{Pu}$ in borosilicate glass compositions as well as the effect of $\mathrm{Pu}$ on glass properties and performance. Based on the review, it was concluded that $1 \mathrm{wt} \% \mathrm{Pu}$ in glass would be expected to be achievable from a solubility perspective and that this concentration represented an upper bound with respect to the ability to supply Pu containing feed to DWPF. The incorporation of Pu in the HLW glass at 1 wt $\%$ was also expected to not have a deleterious effect on glass properties or glass performance. Therefore, testing was conducted at $1 \mathrm{wt} \% \mathrm{Pu}$ in the glass to demonstrate the feasibility of incorporating $\mathrm{Pu}$ at this level in DWPF glass. 
SRNL-STI-2010-00766

Revision 0

\subsection{Experimental Methods}

\subsection{Surrogate Glass Fabrication}

Prior to actual plutonium glass testing, surrogate testing (using $\mathrm{Hf}$ as a surrogate for $\mathrm{Pu}$ ) was conducted to evaluate the homogeneity of significant quantities of $\mathrm{Hf}(\mathrm{Pu})$ in the glass, determine the most appropriate methods to evaluate homogeneity, and to evaluate the impact of Hf loading in the glass on select glass properties. Glass melts were made with a SB2/SB3 Slurry Mix Evaporator $(\mathrm{SME})^{\mathrm{a}}$ simulant and SB6 SME simulant both using hafnium oxide as a $\mathrm{PuO}_{2}$ surrogate. Testing has shown that $\mathrm{HfO}_{2}$ is the best surrogate for $\mathrm{PuO}_{2}$ in glasses from solubility and glass structure perspectives (Lopez, 2003; Shiryaev, 2009). The SB2/SB3 simulant was on hand and available for initial testing. SB6 was selected to correspond with actual SB6 SME product that was used for $\mathrm{Pu}$ testing. The SME products were calcined prior to melting to facilitate processing. $\mathrm{HfO}_{2}$ was added to each SME product to make glass on an equivalent molar ratio to represent $1 \mathrm{wt} \% \mathrm{Pu}$ in the glass. Glasses were also prepared with $\mathrm{Hf}$ at molar ratios to represent $0,0.25,0.5$ and $0.75 \mathrm{wt} \% \mathrm{Pu}$ in the glass to provide intermediary loadings. Glasses were prepared in open crucibles at the nominal $1150{ }^{\circ} \mathrm{C}$ DWPF melter processing temperature using standard benchtop laboratory furnaces. Glasses were prepared using a simple blending process of combining the calcined SME product and $\mathrm{HfO}_{2}$ powder, as well as a more deliberate mixing process involving: mechanical grinding of feed products, melting of feed, re-grinding of glass and re-melting. A Wig-L-Bug® mixer mill fitted with agate cups, balls and caps was used for the grinding stages. These two glass fabrication methods are thought to represent relatively static conditions (simple combining of materials) and well-mixed conditions (that would be anticipated in a full-scale melter).

Crucible melts of glass with the SB6 simulant were also prepared to assess the distribution of Hf within the glass. The melts were prepared by adding mixtures of SME product and $\mathrm{HfO}_{2}$ sequentially to a crucible to result in a crucible that was approximately two-thirds full. The powdered feeds were again made under two conditions: with minimal mixing of $\mathrm{HfO}_{2}$ with the SB6 SME product and with thorough mixing with the SB6 SME product using the Wig-L-Bug® grinder (as described above). In this manner the distribution of Hf could be measured within the crucible to assess any stratification or settling under conditions of little mixing and more thorough mixing/homogenization as would be expected in a glass melter. The glasses were annealed prior to sectioning to preclude cracking.

Glass characteristics and properties were measured on select glasses and included: high temperature viscosity determination, crystallization assessment using XRD, and homogeneity (stratification, settling, etc.) as determined by microscopic analyses.

\subsection{Plutonium Glass Fabrication}

Glass melts were made with: i) SB6 SME simulant slurry and Pu oxide and ii) with actual SB6 $\mathrm{SME}$ product and $\mathrm{Pu}$ oxide. The former was performed to allow a thorough evaluation of the distribution of $\mathrm{PuO}_{2}$ within the glass similar to what was done with the surrogate $\mathrm{SB} 6$ and $\mathrm{HfO}_{2}$ samples (note: the radioactivity levels of actual SB6 "crucible-form" melts were too high to permit removal from the Savannah River National Laboratory (SRNL) Shielded Cells and analysis using SEM/EDS). The testing with actual SB6 and Pu oxide was performed to directly compare the properties of the SB6 glass containing $1 \mathrm{wt} \% \mathrm{Pu}$ to the SB6 DWPF qualification

\footnotetext{
${ }^{a}$ Slurry Mix Evaporator (SME) feed is a mixture of HLW and glass frit that has been preconditioned for feeding to the melter.
} 
glass sample that was recently prepared and analyzed at SRNL (Pareizs, 2010). The SME products were calcined prior to melting to facilitate processing. $\mathrm{PuO}_{2}$ (as an oxide) was added to the SME products at a concentration to represent $1 \mathrm{wt} \% \mathrm{Pu}$ in the glass. Glasses were prepared in open crucibles at the nominal $1150{ }^{\circ} \mathrm{C}$ DWPF melter processing temperature using a high temperature furnace located in the SRNL Shielded Cells. Two glasses using surrogate SB6 and $\mathrm{PuO}_{2}$ were prepared using two techniques: (1) simple mixing of calcined SME product and $\mathrm{PuO}_{2}$ and (2) a more deliberate process involving: mechanical grinding of feed products, melting of feed, re-grinding of glass and re-melting. A Wig-L-Bug ${ }^{\circledR}$ mixer mill fitted with agate cups, balls and caps was used for the grinding stages. Due to a limited quantity of actual SB6 SME DWPF qualification product, only conditions representing good mixing (i.e. mechanical grinding of feed products, melting of feed, re-grinding of glass and re-melting) were used for this glass.

Crucible melts of the $\mathrm{Pu}$ glass were also prepared to assess the distribution of $\mathrm{Pu}$ within the glass. As noted above, this testing was conducted using surrogate SB6 SME product and Pu to facilitate microscopic analyses. The melts were prepared by adding mixtures of SB6 SME product and $\mathrm{PuO}_{2}$ sequentially to a crucible to result in a crucible that was approximately two-thirds full. The melts were again made under two conditions: with minimal mixing of $\mathrm{PuO}_{2}$ with the SB6 SME product and with thorough mixing with the SB6 SME product using the Wig-L-Bug® grinder. The glasses were also annealed prior to sectioning.

Glass characteristics and properties were measured and included: chemical composition measurement, crystallization assessment using x-ray diffraction, and stratification/settling as determined by microscopic analyses. The PCT-A was performed on the actual SB6 glass with 1 wt $\% \mathrm{Pu}$ to compare directly to results for the SB6 DWPF qualification product.

\subsection{Viscosity Measurements}

Viscosity was measured on the Hf surrogate glasses as a function of temperature using a Brookfield DV-II+ high temperature, rotating spindle viscometer for each as-fabricated glass. The measurements were obtained using standard procedures, which are compliant with ASTM C 965-81. In general, the glass was heated to $\sim 1150{ }^{\circ} \mathrm{C}$ in a platinum alloy crucible and maintained until thermal equilibrium was achieved. An initial torque reading (at a constant spindle speed) was taken at this temperature with subsequent measurements at both higher and lower temperatures ranging from $\sim 1050{ }^{\circ} \mathrm{C}$ to $1200{ }^{\circ} \mathrm{C}$ using a hysteresis approach (to the extent possible). The hysteresis approach provided the opportunity to detect any issues associated with either volatilization and/or devitrification over the temperature range of interest. A glass viscosity standard was used to determine the geometric constant of the spindle/cup based on torque and speed. This constant is corrected for temperature effects.

\subsection{Chemical Composition Determination}

The elemental composition of the actual SB6 Pu glass was determined by dissolving samples of ground glass and analyzing the solutions by Inductively Coupled Plasma - Atomic Emission Spectroscopy (ICP-AES) and Inductively Coupled Plasma - Mass Spectroscopy (ICP-MS). Fines resulting from grinding the PCT-A sample were used for this analysis. The glass was digested by two separate methods: mixed acid dissolution and sodium peroxide fusion. All cations except $\mathrm{Pu}$ were determined using ICP-AES. The Pu concentration in the glass was determined using ICPMS.

\subsection{Crystallinity Assessment using XRD}

Quenched glass samples were evaluated for crystallization using XRD. Samples were run under conditions providing a detection limit of approximately $0.5 \mathrm{vol} \%$. That is, if crystals (or 
undissolved solids) were present at 0.5 vol \% or greater, the diffractometer would not only be capable of detecting the crystals but would also allow a qualitative determination of the type of crystal(s) present. Otherwise, a characteristically high background devoid of crystalline spectral peaks indicates that the glass product is amorphous, suggesting either a completely amorphous product or that the degree of crystallization is below the detection limit.

\subsection{Homogeneity Assessment using Electron Microscopy}

Figure 2 provides a schematic of how the glass "crucible-forms" were sectioned. The sections were analyzed using SEM/EDS. The analyses included examining the glass at high magnifications to look for heterogeneities within the glass and at low magnifications to assess the elemental distribution from top to bottom in the crucible. The latter was assessed by performing elemental area scans using EDS to "map" the elemental distribution in the glass and by line scans to evaluate specific regions. Microscopic analyses of "crucible-form" sections were conducted on both Hf surrogate and Pu glasses. However, it should be noted that attempts to do elemental area scans and line scans on the Pu glasses were not successful. There was significant overlap of the distinct $\mathrm{Pu}$ energy peaks in the EDS analyses with other elements (namely $\mathrm{Ca}$ and $\mathrm{K}$ ) that prohibited obtaining semi-quantitative $\mathrm{Pu}$ concentration data using the system software. Therefore, analysis of the relative peak intensity of the major $\mathrm{Pu}$ peak was used to assess homogeneity of $\mathrm{Pu}$ within the "crucible-form" samples.

A portion of the fines resulting from preparation of the actual SB6 Pu glass for the PCT was also evaluated using SEM/EDS. Analyzing glass in this manner provides a significant amount of glass surface area for analysis to examine for heterogeneities, crystals, etc. To facilitate examination in the SEM, the ground glass samples were placed on an aluminum stub.

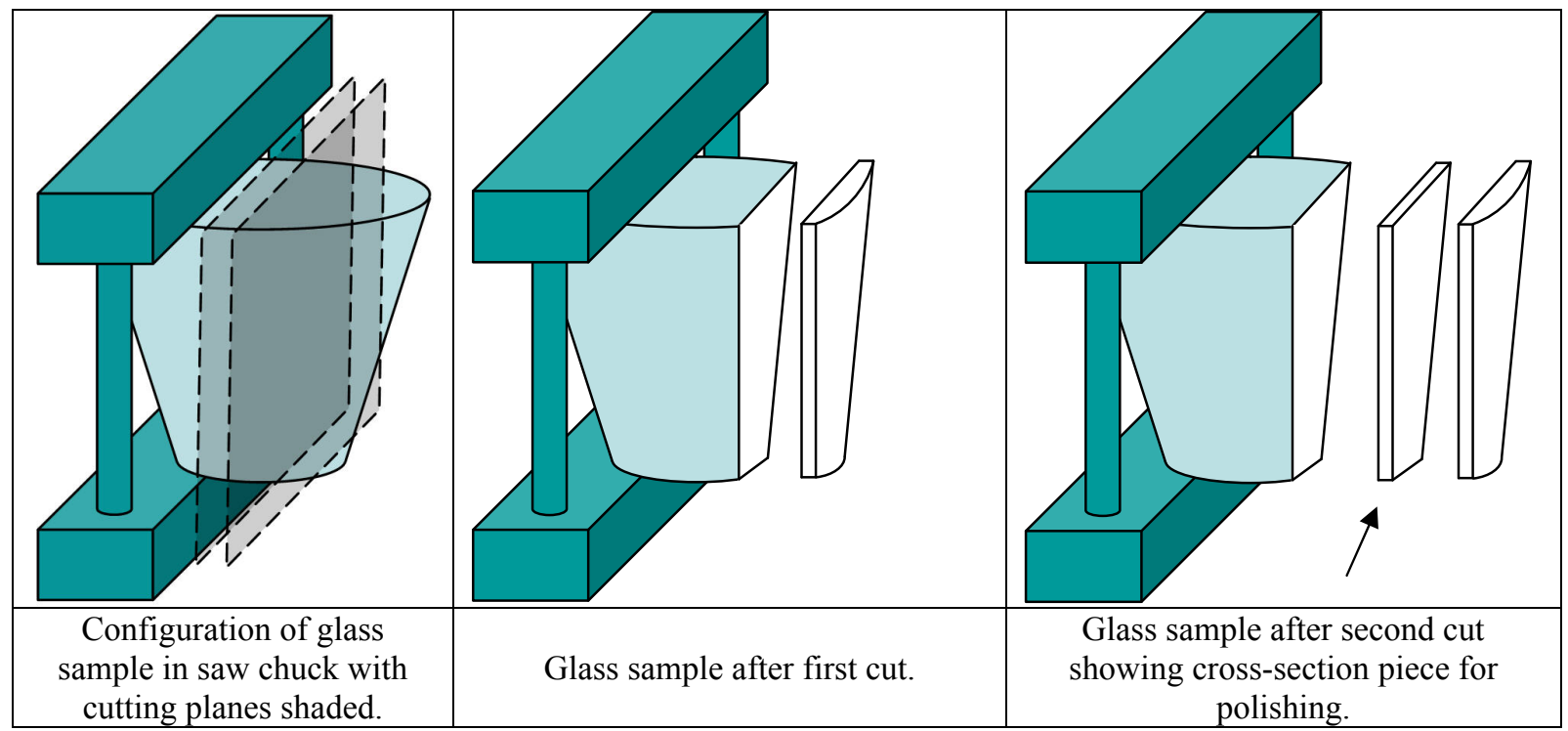

Figure 2. Schematic showing sectioning of glass "crucible-forms" for subsequent analyses using SEM/EDS.

\subsection{Product Consistency Test to Determine Durability}

The PCT was performed in triplicate on a quenched sample of the actual SB6 glass containing 1 wt $\% \mathrm{Pu}$ to assess chemical durability using the ASTM C-1285 Procedure (ASTM C-1285, 2002). 
The method "A" procedure was followed. Also included in the PCT testing were the Environmental Assessment (EA) glass, the Approved Reference Material (ARM) glass, and blanks. The resulting solutions (leachates) were analyzed via ICP-AES for $\mathrm{Si}, \mathrm{B}, \mathrm{Na}$, and $\mathrm{Li}$ release. The leachates were measured for Pu using ICP-MS. 


\subsection{Results and Discussion}

\subsection{Viscosity Measurements on Hf Surrogate Glasses}

Viscosity measurements were conducted on both SB6 and SB2/3 glasses containing no Hf and with $\mathrm{Hf}$ to represent $1 \mathrm{wt} \% \mathrm{Pu}$ in glass on a molar basis. Figure 3 shows the viscosity results and indicated that there was no practical impact on viscosity by including Hf to represent $1 \mathrm{wt} \% \mathrm{Pu}$ in glass on a molar basis. It should be further noted that the viscosities of the glasses were all predictable using the current DWPF viscosity model with a $95 \%$ confidence interval. Viscosity measurements were only conducted on glasses with no added $\mathrm{HfO}_{2}$ and glasses with $\mathrm{HfO}_{2}$ at the highest level studied (to represent $1 \mathrm{~mol} \% \mathrm{Pu}$ in glass) for efficiency. If significant viscosity differences were noted in this first set of glasses, glasses with intermediary levels of added $\mathrm{HfO}_{2}$ would have been measured.

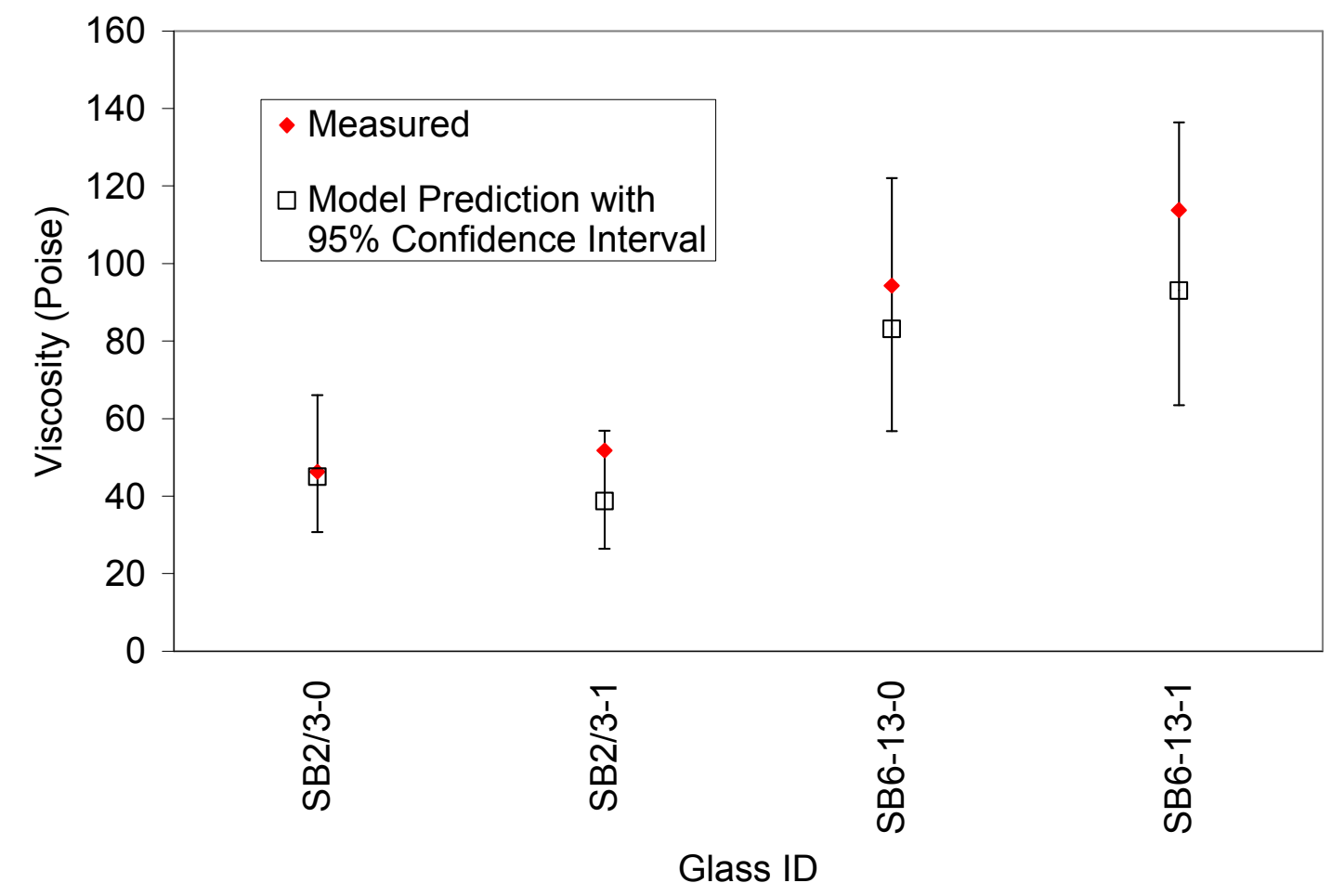

Figure 3. Viscosity at $1150{ }^{\circ} \mathrm{C}$ for a mixture of surrogate SB2 and SB3 and SB6 with no added Hf (SBX-0) and with Hf added to represent $1 \mathrm{wt} \% \mathrm{Pu}$ in glass on a equal molar basis (SBX-1).

\subsection{Crystallinity Assessment in Hf Surrogate Glasses}

Samples of the quenched Hf surrogate SB6 glasses were submitted for XRD to assess the crystallinity of the glasses. Specific attention was given to looking for the formation of Hfcontaining phases that would point to similar Pu-containing phases in the $\mathrm{Pu}$ glasses. No Hfcontaining phases were identified in the glasses. In the surrogate SB6 glasses, a small concentration of a spinel phase (trevorite) was identified (Figure 4). This phase is consistent with DWPF-type glasses. The relative amount of trevorite appeared to be equivalent for the glass with $0 \mathrm{wt} \% \mathrm{Hf}$ (Figure 4a) and $\mathrm{Hf}$ on an equivalent molar basis to $1 \mathrm{wt} \% \mathrm{Pu}$ in glass (Figure $4 \mathrm{~b}$ ). 
Glasses prepared with intermediary levels of $\mathrm{HfO}_{2}$ were also analyzed using XRD. Similar relative amounts of trevorite were identified in those samples and no evidence of $\mathrm{HfO}_{2}$ containing phases was found.

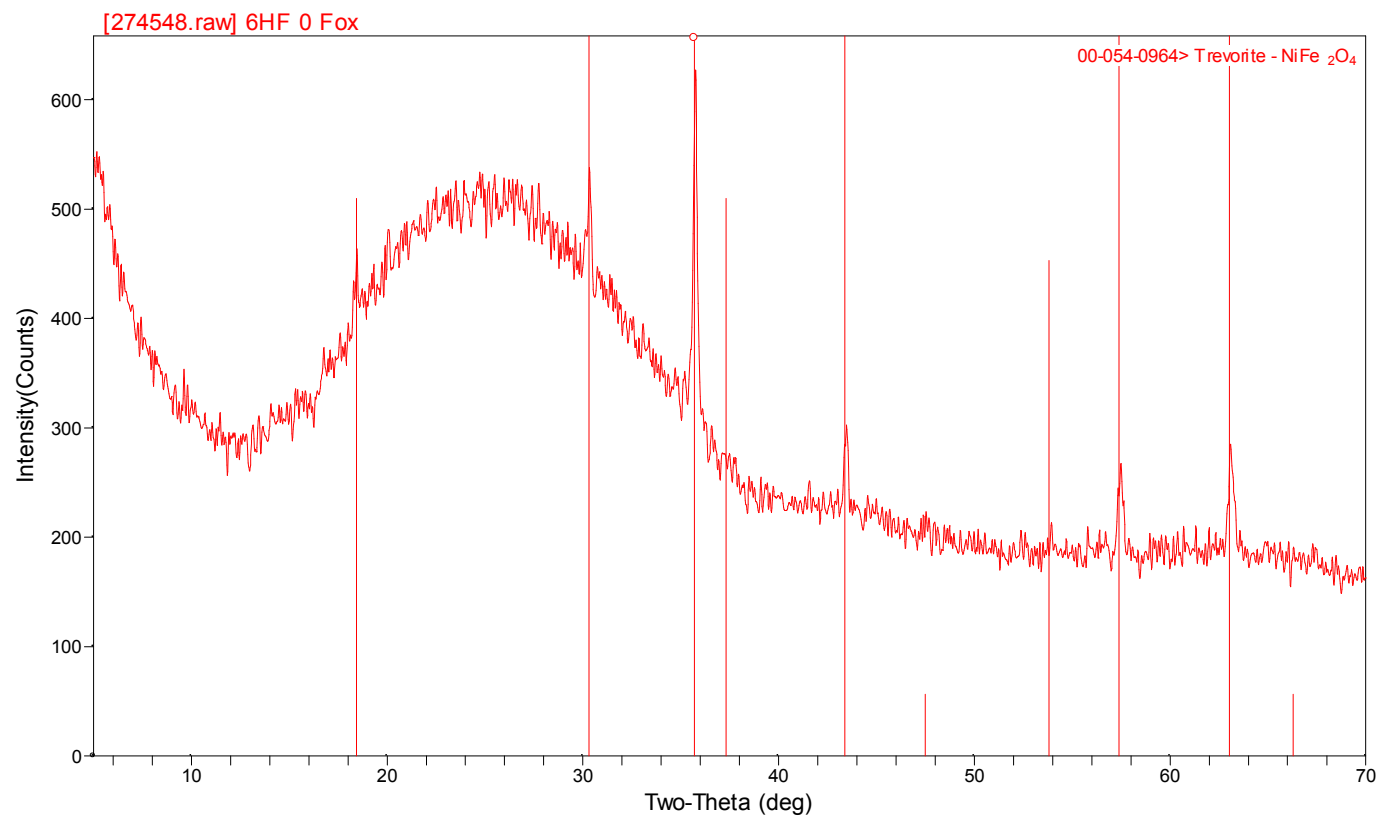

(a)

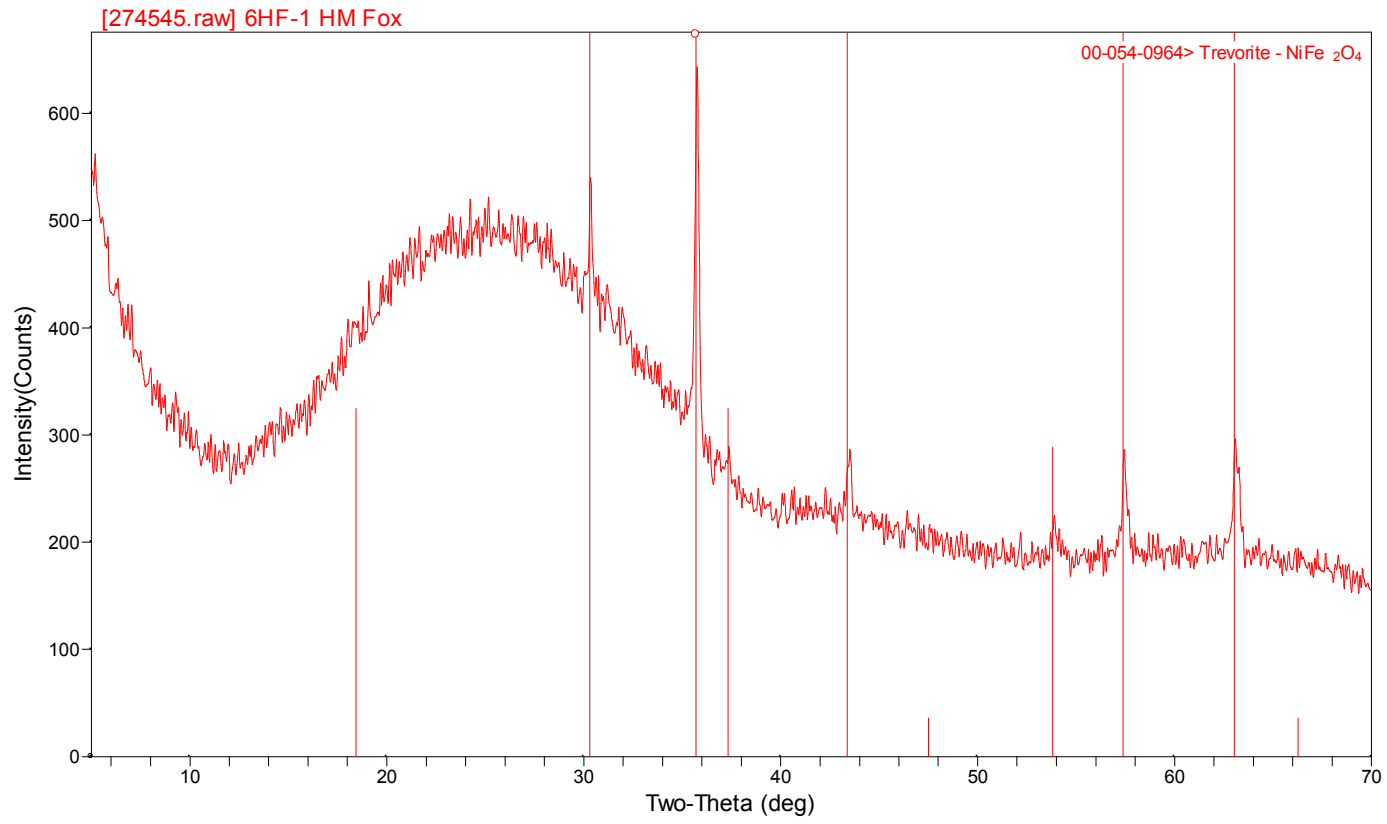

(b)

Figure 4. XRD patterns of (a) surrogate SB6 with $0 \mathrm{wt} \% \mathrm{Hf}$ and (b) surrogate SB6 with Hf on an equivalent molar basis to $1 \mathrm{wt} \% \mathrm{Pu}$ in glass that underwent minimal mixing. 


\subsection{Homogeneity Assessment of Hf Surrogate Glasses}

Figure 5 shows the results of the SEM/EDS area scans for the Hf glass with minimal mixing. It is evident that there was stratification of $\mathrm{HfO}_{2}$ in the crucible under these relatively static conditions. In fact, at high magnifications there was evidence of undissolved $\mathrm{HfO}_{2}$ at the bottom of the crucible. A section of this same glass sample was analyzed by XRD and no evidence of undissolved $\mathrm{HfO}_{2}$ was noted (Figure 4). These results indicated that generally $\mathrm{HfO}_{2}$ was dissolved in the glass except in small regions where the solubility limit was exceeded and adequate mixing did not occur.

Figure 6 shows the results of the well-mixed sample. The distribution of $\mathrm{HfO}_{2}$ within the crucible appeared uniform (within the analytical error associated with the instrument). Figure 7 shows a plot where "line scans" were conducted at the top, middle and bottom of the crucible to further assess $\mathrm{HfO}_{2}$ distribution. These analyses also indicated that the Hf was uniformly dispersed within the glass. 


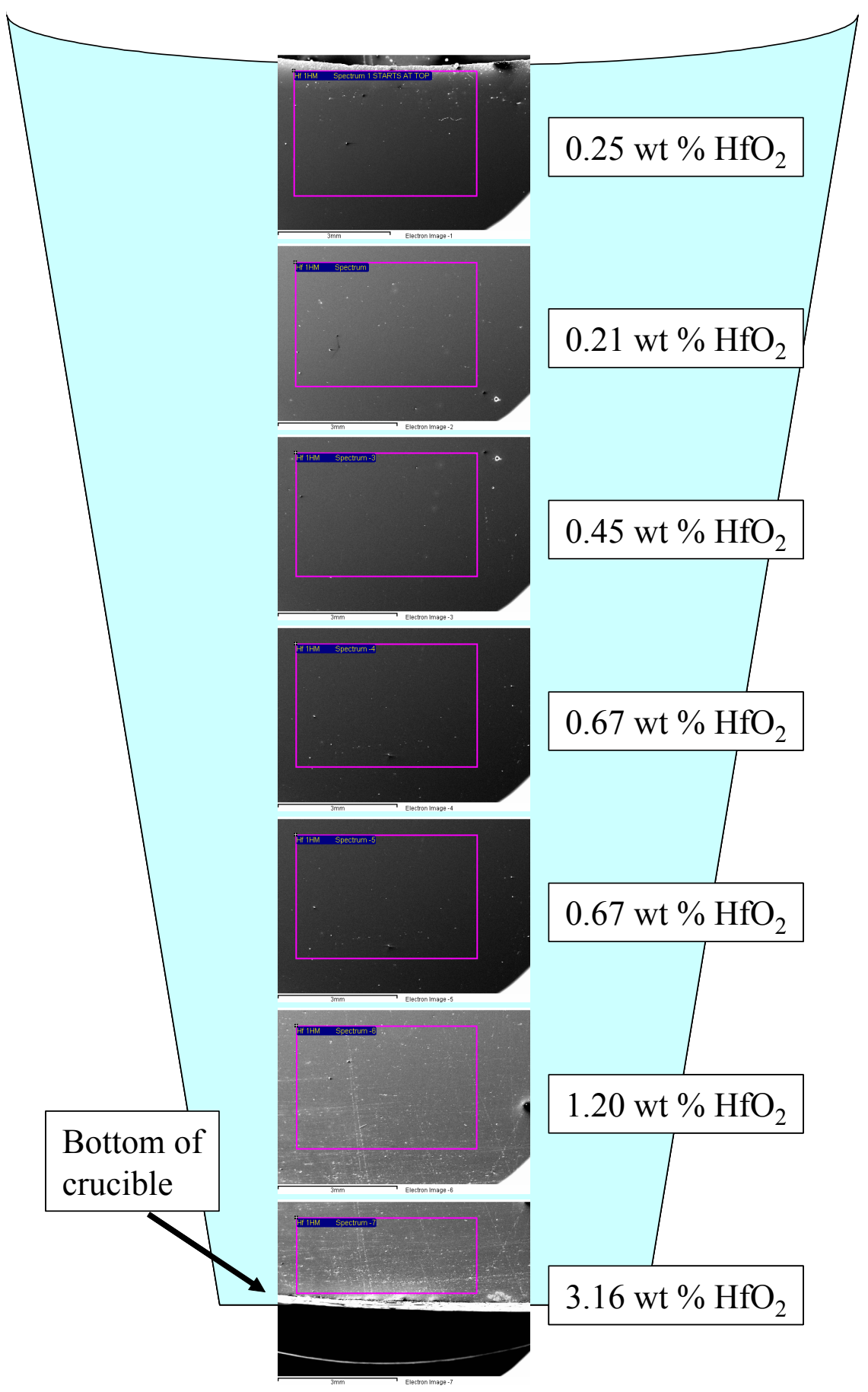

Figure 5. SEM/EDS mapping of $\mathrm{HfO}_{2}$ distribution within glass "crucible-form" for SB6 with $\mathrm{Hf}$ to represent $1 \mathrm{wt} \%$ Pu on a molar basis that underwent minimal mixing. Figure depicts "crucible-form" section with scans from top to bottom of crucible. 


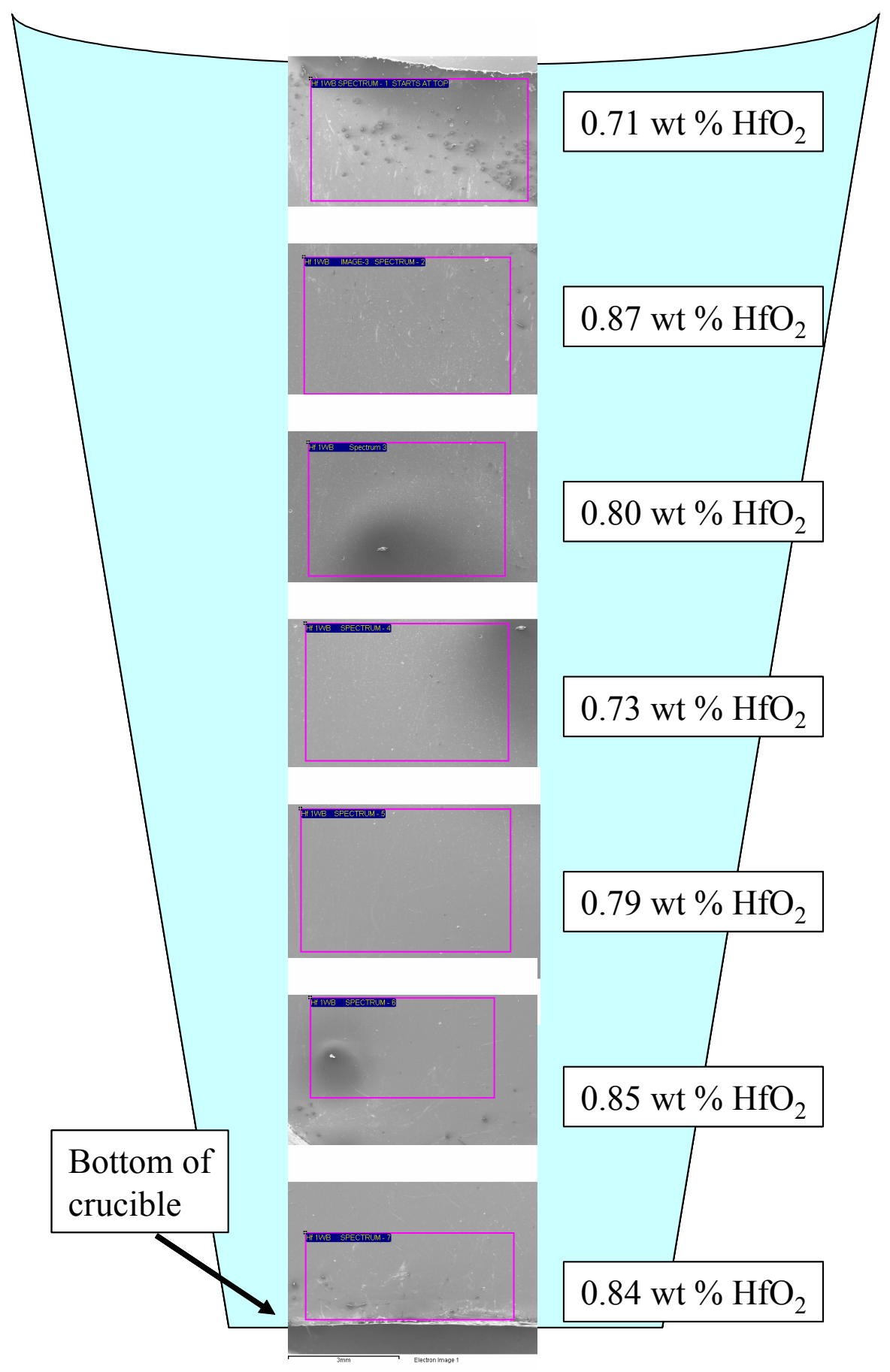

Figure 6. SEM/EDS mapping of $\mathrm{HfO}_{2}$ distribution within glass "crucible-form" for SB6 with $\mathrm{Hf}$ to represent $1 \mathrm{wt} \% \mathrm{Pu}$ on a molar basis prepared under well-mixed conditions. Figure depicts "crucible-form" section with scans from top to bottom of crucible. 


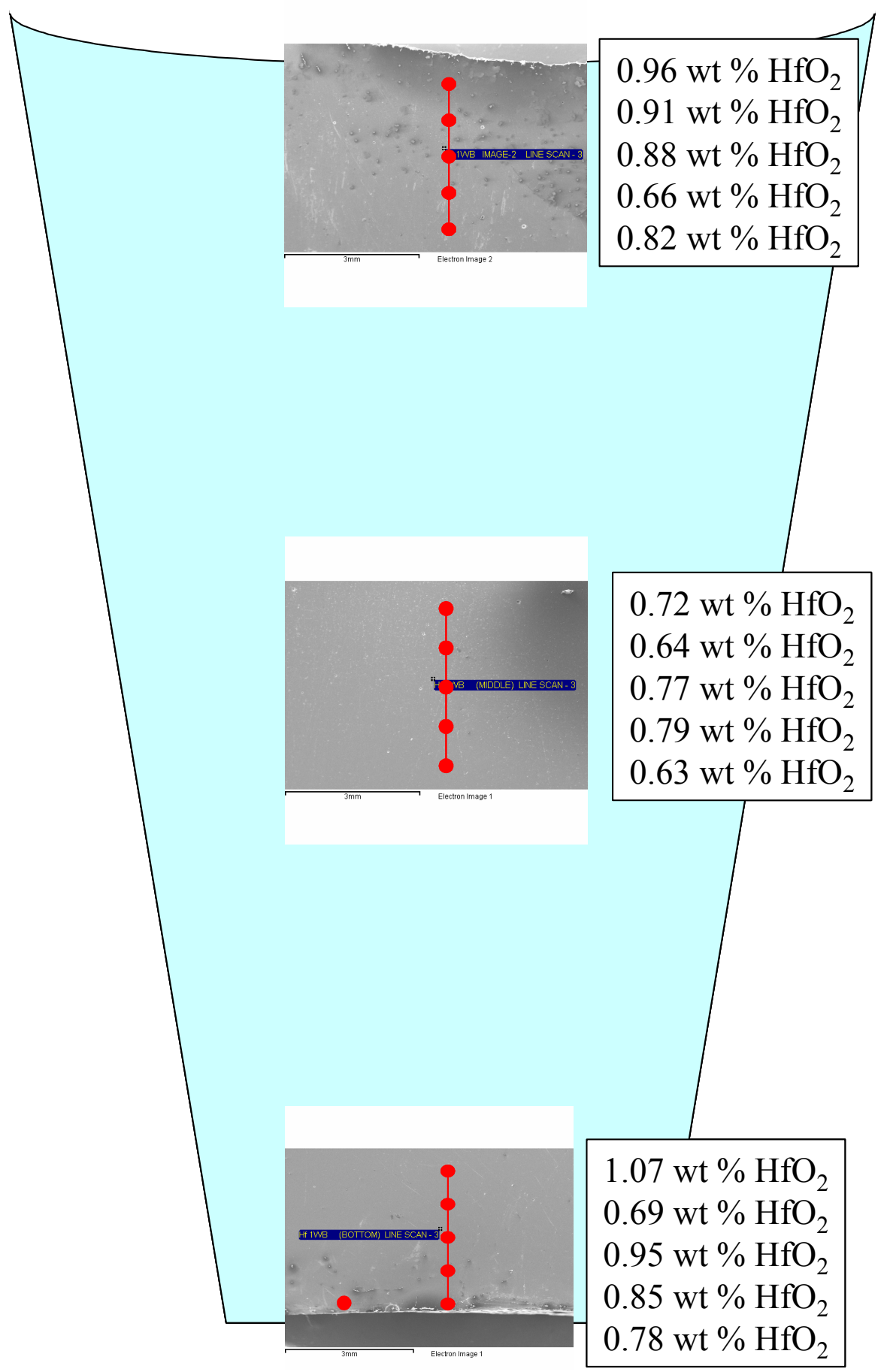

Figure 7. SEM/EDS line scans of $\mathrm{HfO}_{2}$ distribution within glass "crucible-form" for SB6 with $\mathrm{Hf}$ to represent $1 \mathrm{wt} \% \mathrm{Pu}$ on a molar basis prepared under well-mixed conditions. Figure depicts "crucible-form" section with line scans in specific regions. 


\subsection{Chemical Composition of the Actual SB6 Glass with Pu}

Table 1 contains the glass composition results for the actual SB6 glass containing $1 \mathrm{wt} \% \mathrm{Pu}$. The glass sample analyzed was from fines (-200 mesh) resulting from grinding the sample for PCT. The sum of the oxides in Table 1 is equal to $100.74 \mathrm{wt} \%$, implying that the glass dissolution was adequate. At $1 \mathrm{wt} \% \mathrm{Pu}$ in the glass, a $\mathrm{PuO}_{2}$ concentration of $1.13 \mathrm{wt} \%$ would be expected. The measured value of $1.11 \mathrm{wt} \%$ provided an indication that the $\mathrm{PuO}_{2}$ was distributed and contained in the glass (i.e. not volatilized). As expected, the composition of this glass was very close to the composition of the SB6 qualification glass (Pareizs, 2010). The SB6 glass with $\mathrm{Pu}$ did contain higher concentrations of $\mathrm{Fe}_{2} \mathrm{O}_{3}, \mathrm{Cr}_{2} \mathrm{O}_{3}$ and $\mathrm{NiO}$ due to some contamination from the grinder used to prepare the PCT samples (and obviously higher $\mathrm{PuO}_{2}$ concentration).

Table 1. Chemical Composition of Actual SB6 Glass with 1 wt\% Pu

\begin{tabular}{||c|c|c|c|c||}
\hline Oxide & wt \% & & Oxide & wt \% \\
\hline $\mathrm{Al}_{2} \mathrm{O}_{3}$ & 8.88 & & $\mathrm{Na}_{2} \mathrm{O}$ & 13.08 \\
\hline $\mathrm{B}_{2} \mathrm{O}_{3}$ & 5.15 & & $\mathrm{Nd}_{2} \mathrm{O}_{3}$ & $\mathrm{ND}$ \\
\hline $\mathrm{BaO}$ & 0.05 & & $\mathrm{NiO}$ & 1.02 \\
\hline $\mathrm{CaO}$ & 0.38 & & $\mathrm{P}_{2} \mathrm{O}_{5}$ & 0.13 \\
\hline $\mathrm{Ce}_{2} \mathrm{O}_{3}$ & 0.02 & & $\mathrm{PbO}$ & $\mathrm{ND}$ \\
\hline $\mathrm{Cr}_{2} \mathrm{O}_{3}$ & 0.35 & & $\mathrm{SO}_{4}{ }^{2-}$ & 0.30 \\
\hline $\mathrm{CuO}$ & 0.12 & & $\mathrm{SiO}_{2}$ & 51.13 \\
\hline $\mathrm{Fe}_{2} \mathrm{O}_{3}$ & 8.29 & & $\mathrm{SrO}^{2}$ & 0.02 \\
\hline $\mathrm{K}_{2} \mathrm{O}$ & 0.04 & & $\mathrm{ThO}_{2}$ & 1.40 \\
\hline $\mathrm{La}_{2} \mathrm{O}_{3}$ & 0.04 & & $\mathrm{TiO}_{2}$ & 0.020 \\
\hline $\mathrm{Li}_{2} \mathrm{O}$ & 5.17 & & $\mathrm{U}_{3} \mathrm{O}_{8}$ & 1.23 \\
\hline $\mathrm{MgO}_{\mathrm{MnO}} \mathrm{O}$ & 2.18 & & $\mathrm{ZnO}$ & 0.04 \\
\hline $\mathrm{MnO}$ & & $\mathrm{ZrO}_{2}$ & 0.14 \\
\hline $\mathrm{MoO}$ & 0.01 & & $\mathbf{P u O}_{2}$ & $\mathbf{1 . 1 1}$ \\
\hline
\end{tabular}

\subsection{Crystallinity Assessment in Pu Glasses}

XRD was performed on the actual SB6 glass with $1 \mathrm{wt} \% \mathrm{Pu}$. The results showed that the glass was completely amorphous within XRD detection limits (Figure 8). There was no evidence of any $\mathrm{Pu}$-containing crystalline phases or other crystalline phases (e.g. spinel) forming in the glass.

XRD was also performed on samples of the surrogate SB6 glasses with $1 \mathrm{wt} \% \mathrm{Pu}$ prepared under well-mixed and minimal mixing conditions (Figure 9). These samples were randomly obtained during sectioning of the "crucible-form" glasses. There was clear evidence of the presence of undissolved $\mathrm{PuO}_{2}$ in the minimally-mixed sample (Figure 9a) and no evidence of undissolved $\mathrm{PuO}_{2}$ in the well-mixed sample (Figure 9b). Both samples did show evidence of spinel (trevorite) crystals in the glass. The presence of spinel was consistent with the Hf glasses prepared with the surrogate SB6 material (Figure 4). 
SRNL-STI-2010-00766

Revision 0

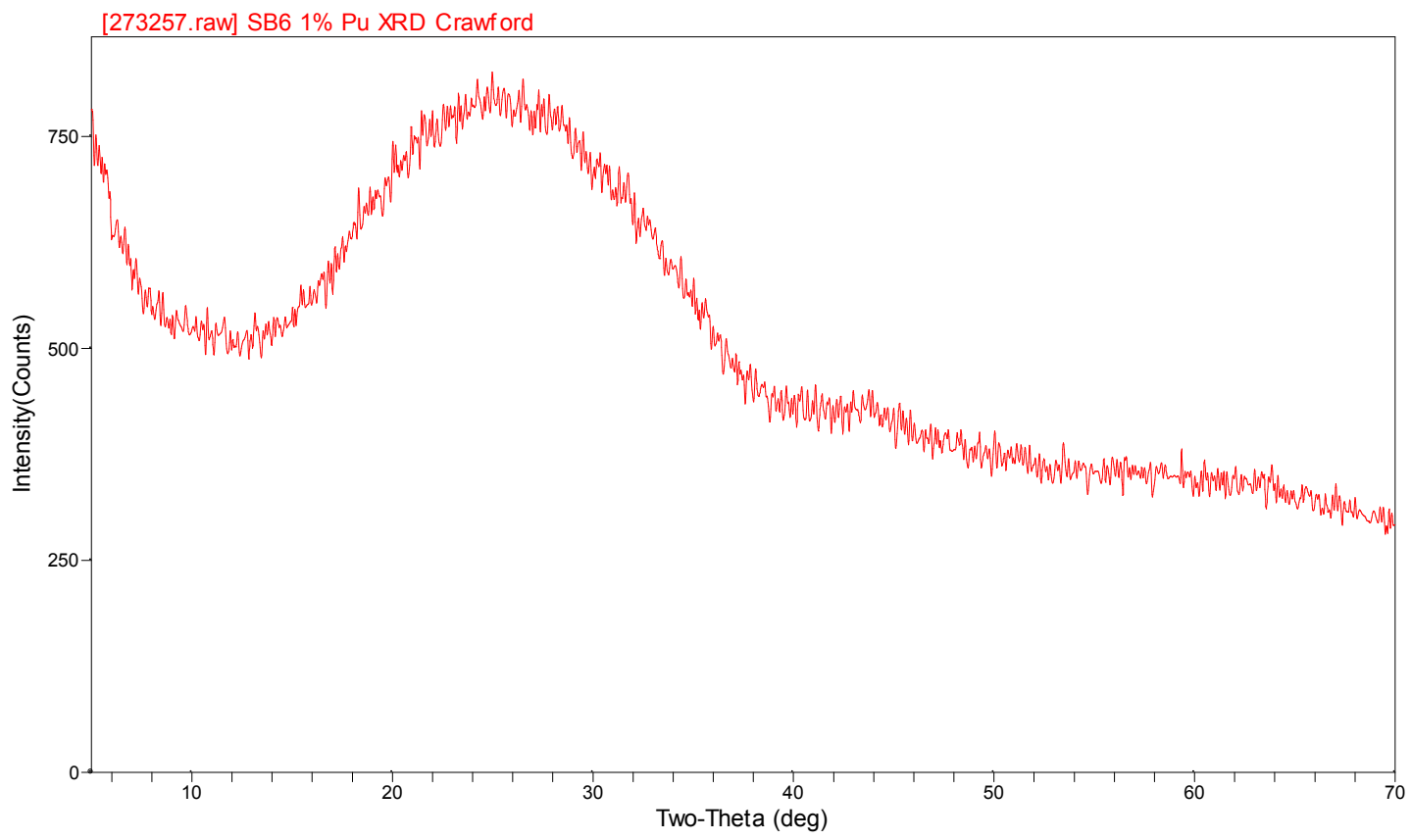

Figure 8. XRD pattern of actual SB6 glass with $1 \mathrm{wt} \% \mathrm{Pu}$ in the glass prepared under well-mixed conditions. 
SRNL-STI-2010-00766

Revision 0

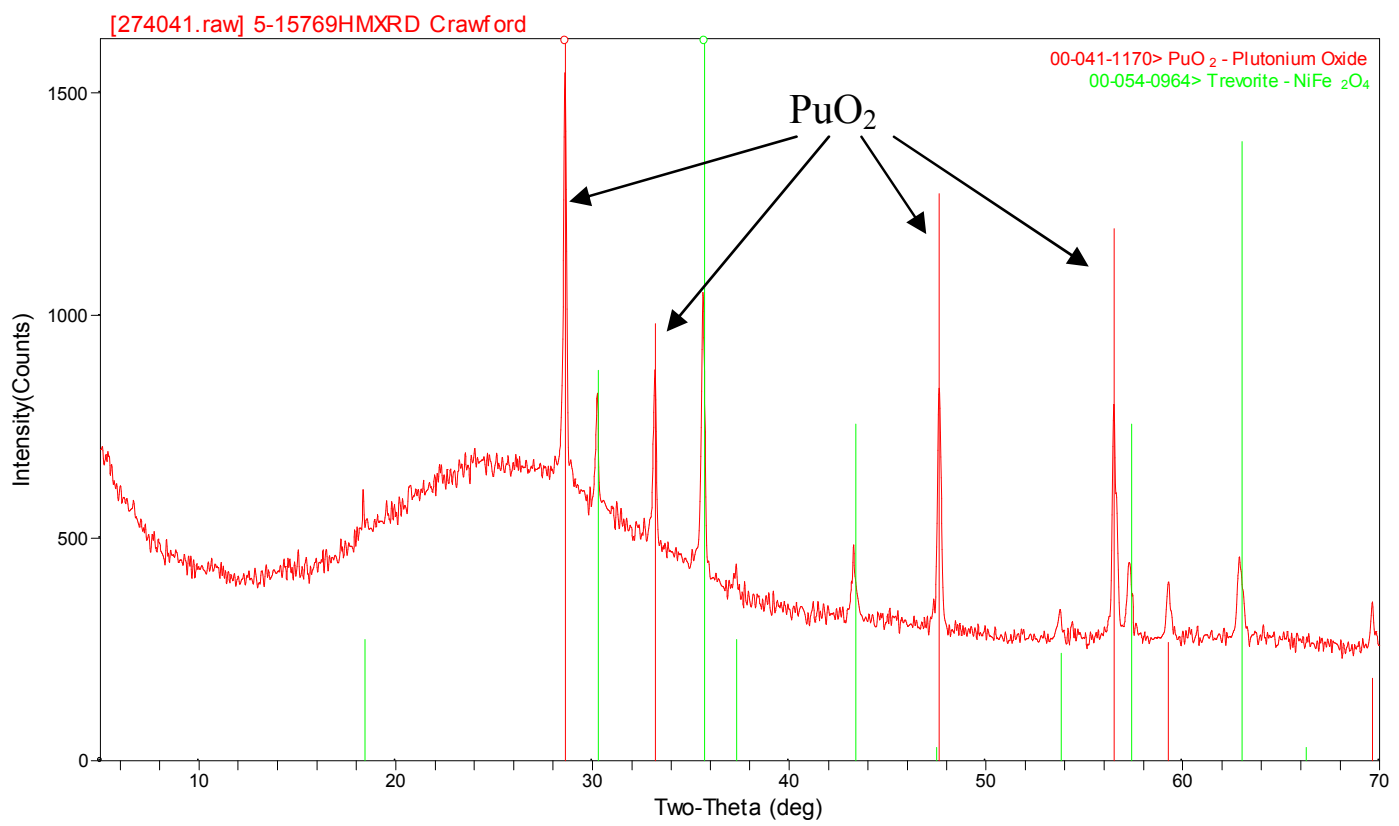

(a)

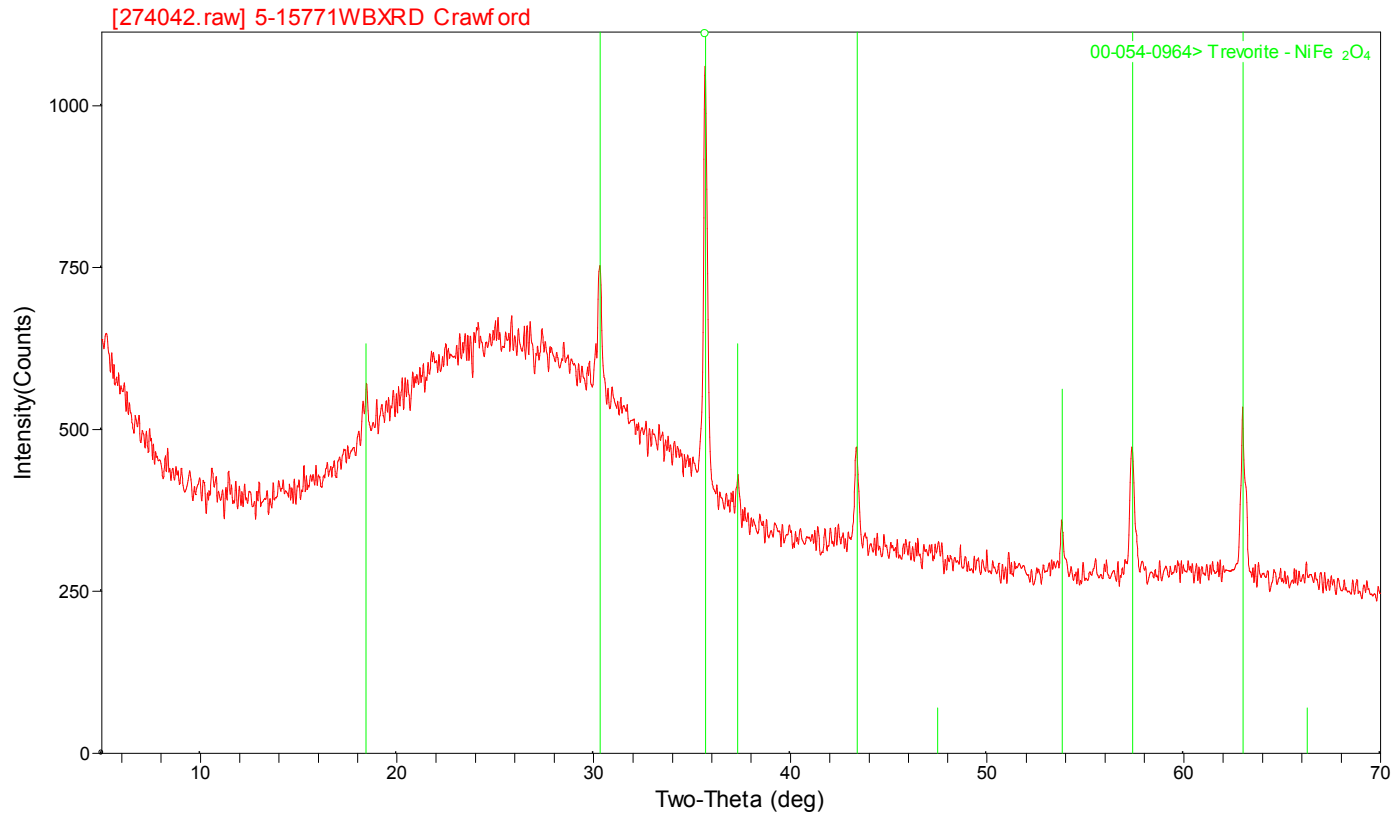

(b)

Figure 9. X-ray diffraction patterns of (a) surrogate SB6 with $1 \mathrm{wt} \% \mathrm{Pu}$ - minimal mixing conditions and (b) surrogate SB6 with 1 wt \% Pu - well-mixed conditions. 


\section{6 $\underline{\text { Homogeneity Assessment of Pu Glasses }}$}

Electron microscopy analysis was completed on glass fines (-200 mesh) resulting from sample preparation of the actual SB6 Pu glass for the PCT-A. Analysis of the fines provided a large amount of glass surface area to look for crystallization, undissolved $\mathrm{PuO}_{2}$, and other heterogeneities. This analysis showed that there was no crystallization within the glass and, furthermore, no undissolved $\mathrm{PuO}_{2}$ was detected within the glass matrix (Figure 10). The SEM results were consistent with the XRD results shown in Figure 8.

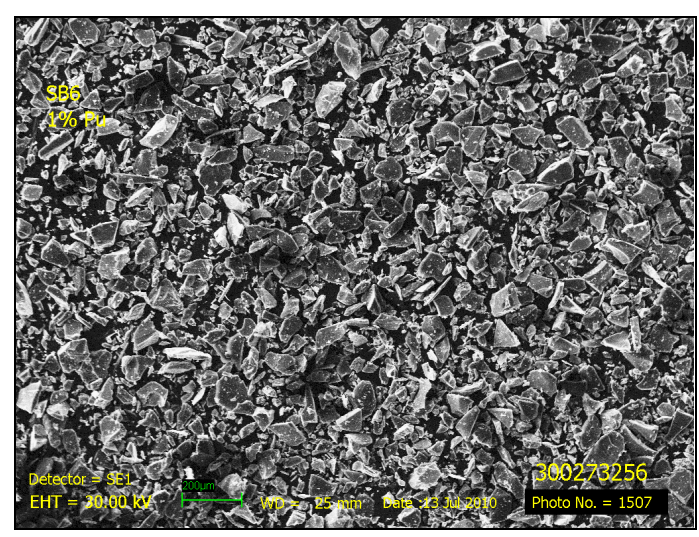

(a)

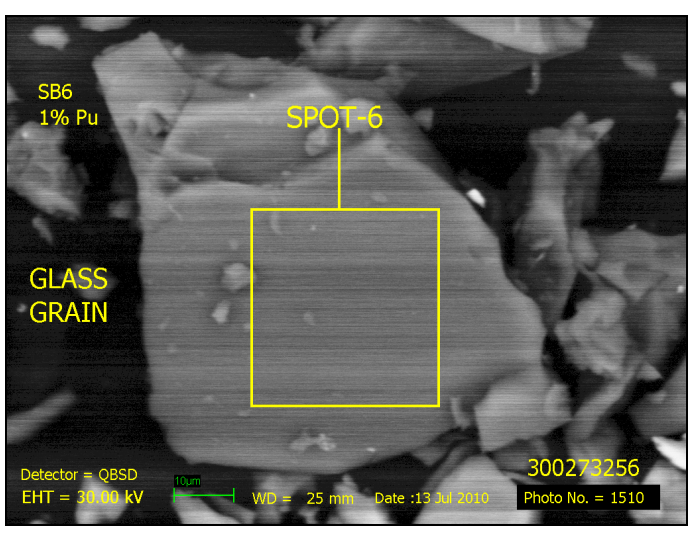

(b)

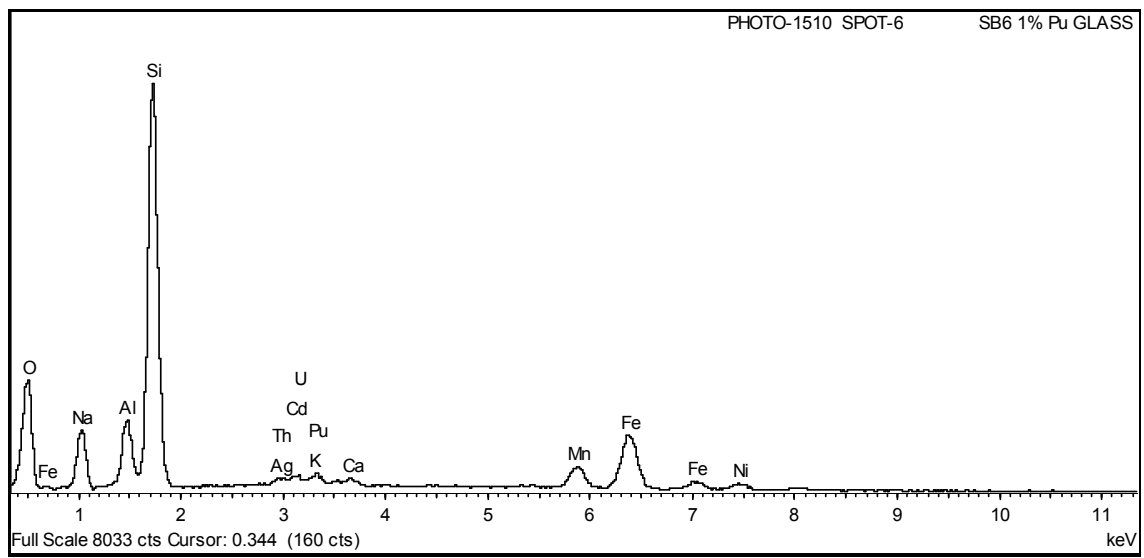

(c)

Figure 10. SEM/EDS data for actual SB6 glass with $1 \mathrm{wt} \%$ Pu prepared under well-mixed conditions - (a) low magnification micrograph of fines, (b) higher magnification micrograph of glass shard, (c) EDS spectrum of area defined by the box in (b).

The surrogate SB6 "crucible-form" samples with $1 \mathrm{wt} \% \mathrm{Pu}$ were also analyzed using SEM/EDS. An area of undissolved $\mathrm{PuO}_{2}$ was clearly evident in the glass prepared with minimal mixing (Figure 11) consistent with the XRD analysis (Figure 9a). The $\mathrm{PuO}_{2}$ in this region had settled out due to less mixing and did not dissolve into the glass under the relatively static melt conditions. 


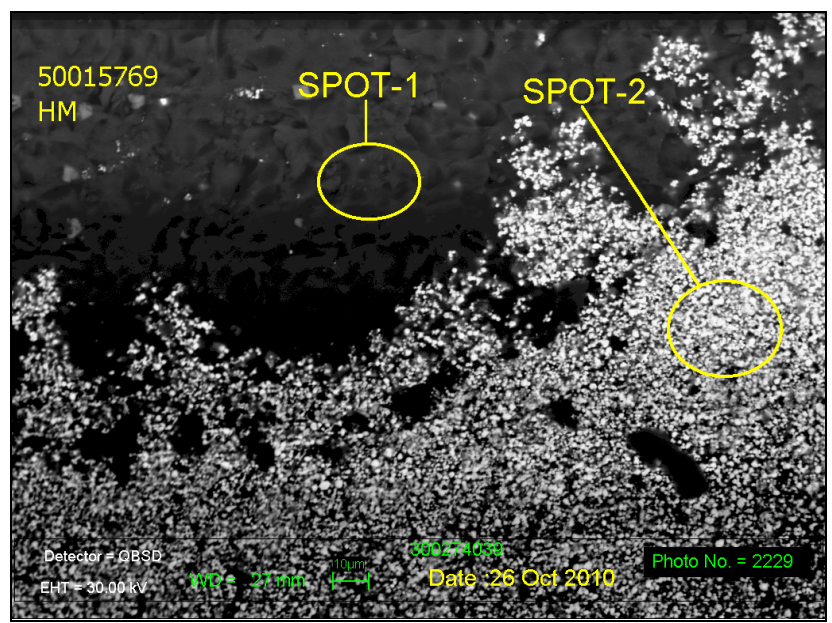

(a)

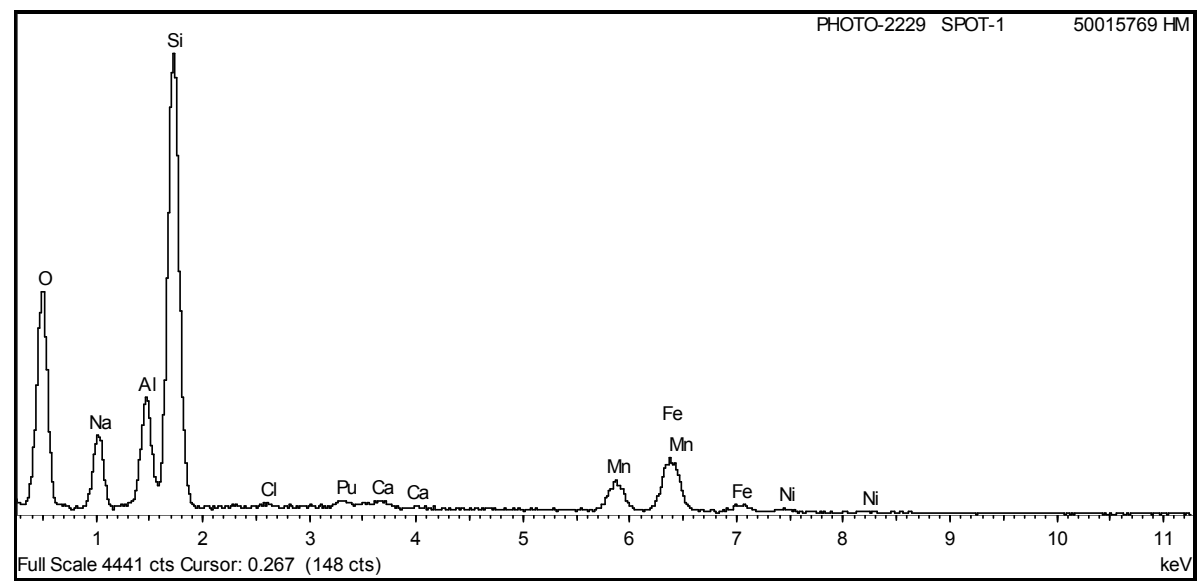

(b)

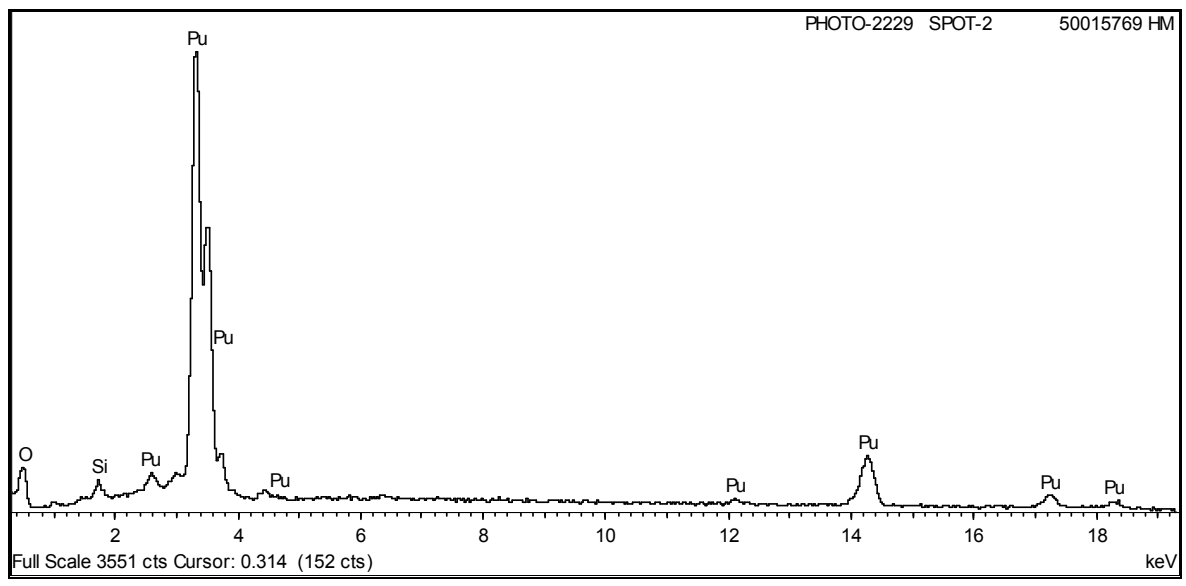

(c)

Figure 11. SEM/EDS data for surrogate SB6 glass with 1 wt \% Pu prepared with minimal mixing. Undissolved $\mathrm{PuO}_{2}$ is evident in micrograph (a) and in EDS spectra (c). 
There was no evidence of undissolved $\mathrm{PuO}_{2}$ in the well-mixed glass prepared using the Wig-LBug ${ }^{\circledR}$. In this glass only the trevorite phase was seen in the glass matrix (Figure 12). The SEM results for this sample were consistent with the XRD results shown in Figure 9b. The mottled appearance of the glass in these micrographs was due to the sectioning process. It was not feasible to polish the glass samples prior to SEM/EDS examination. It should be noted that in an effort to ensure that the crucible-form samples did not crack, the crucibles were initially slow cooled in the furnace to about $800{ }^{\circ} \mathrm{C}$ after melting at $1150{ }^{\circ} \mathrm{C}$. This slow cooling likely exacerbated the formation of trevorite.

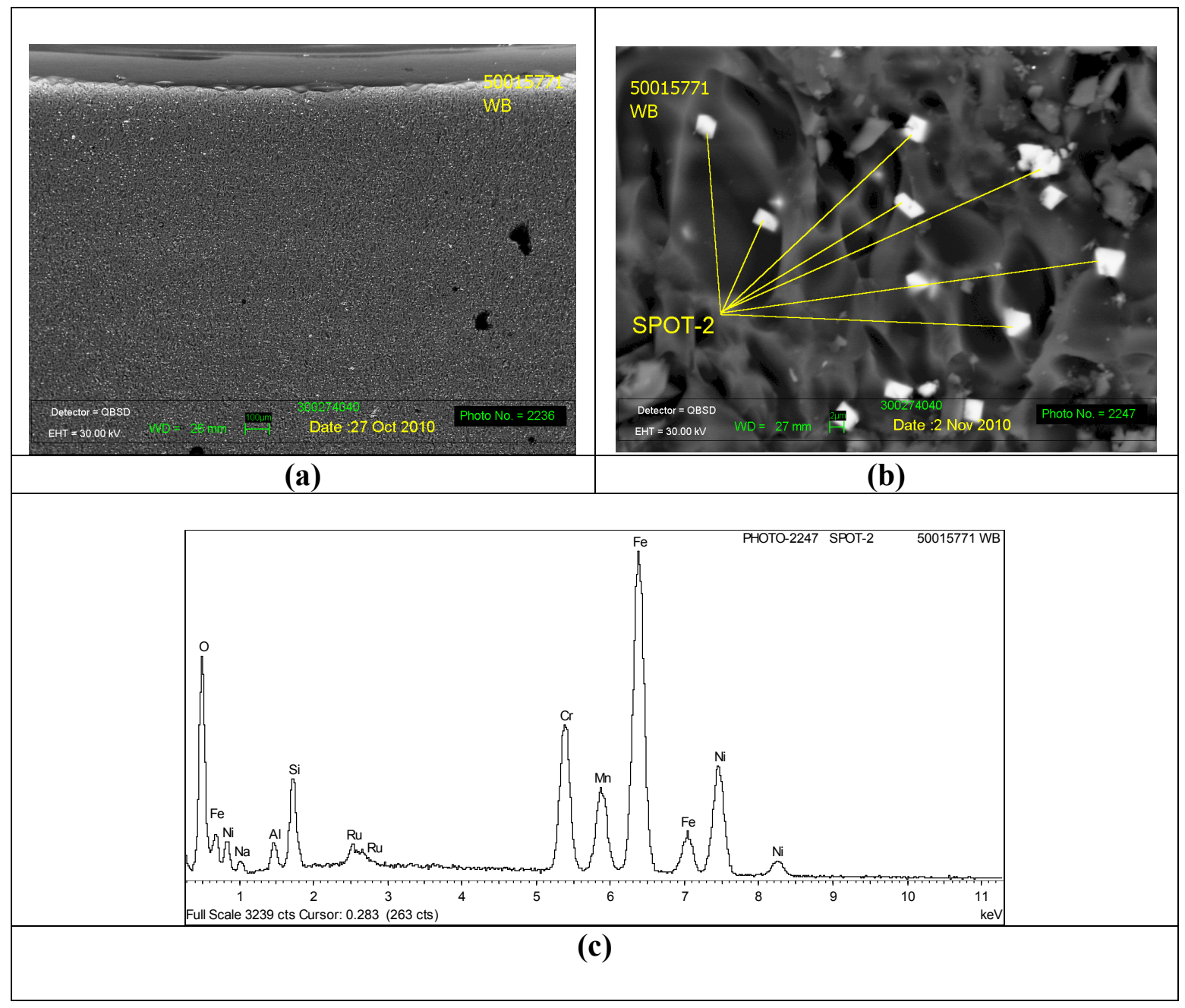

Figure 12. SEM/EDS data for surrogate SB6 glass with 1 wt \% Pu prepared under wellmixed conditions. Only spinel (trevorite) crystals were eveident in the glass (b) and (c).

As mentioned previously, it was not possible to obtain semi-quantitative data regarding the distribution of $\mathrm{Pu}$ within the "crucible-form" sectioned samples. The EDS spectra were, however, analyzed with respect to the relative peak intensities of the "Pu-line" in the energy spectra. Figure 13 shows these data in graphical form. The $\mathrm{Pu}-\mathrm{M} \alpha$ and $\mathrm{Pu}-\mathrm{M} \beta$ and $\mathrm{Ca}-\mathrm{K} \alpha$ lines are plotted. Data are presented for the well-mixed sample (labeled as Wiggle Bug in Figure 13), minimally-mixed sample (labeled as Hand mixed in Figure 13) and the area with undissolved $\mathrm{PuO}_{2}$ in the minimally-mixed sample (labeled as Unmixed Pu in Figure 13). Data for the well- 
mixed and minimally-mixed samples are also plotted from data obtained at the top and bottom of the "crucible-form" section. From these data, the concentration of $\mathrm{Pu}$ in the well-mixed sample (Wiggle Bug) looked to be consistent in the top and bottom of the "crucible-form" section. The concentration at the top and bottom of the minimally-mixed sample also looked to be consistent but based on the relative peak intensity could be considered to be lower than in the well-mixed sample (due to the stratified undissolved $\mathrm{PuO}_{2}$ area in the melt).

\section{Hand Mixed vs. Wiggle Bug}

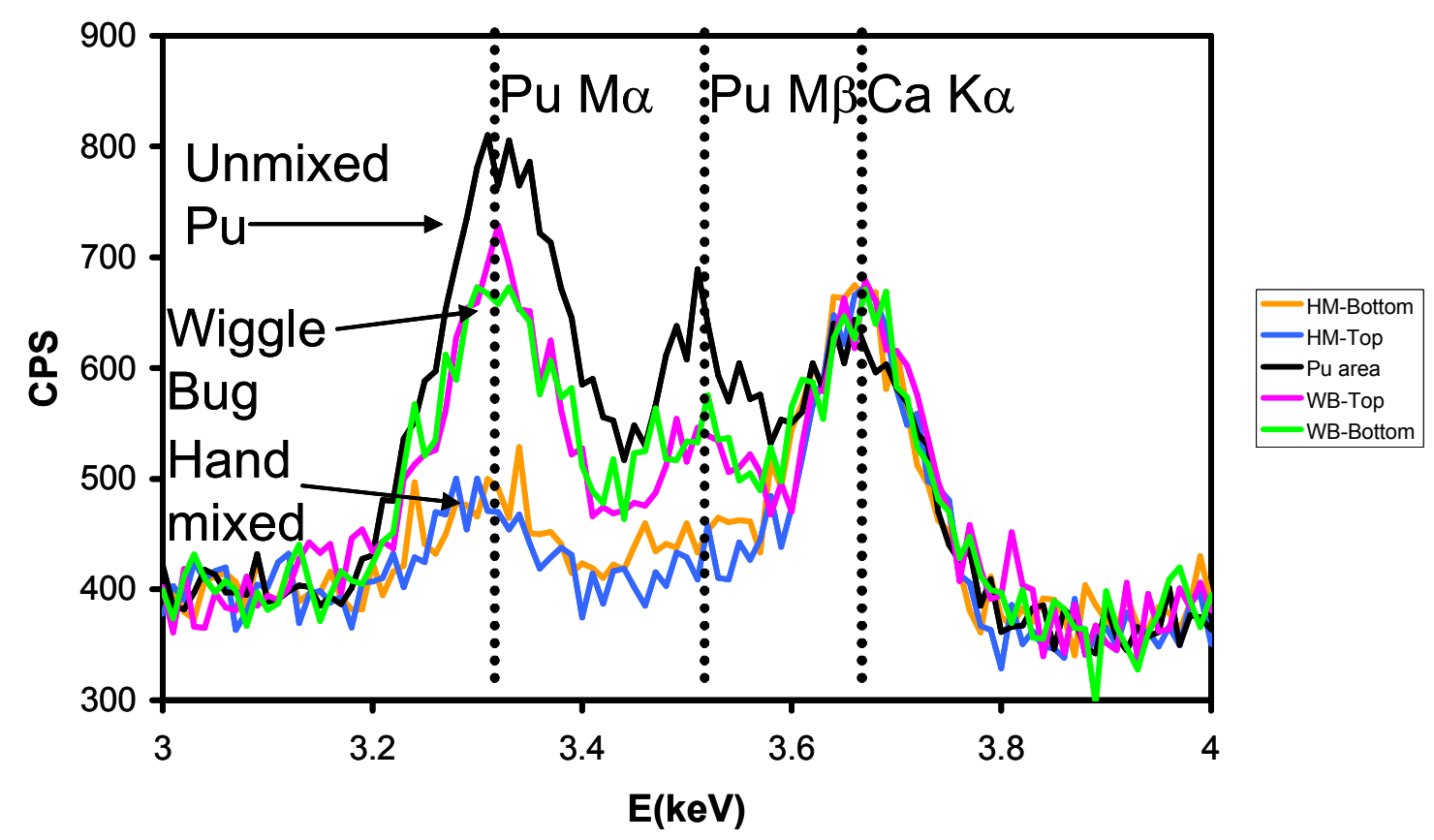

Figure 13. EDS spectra of surrogate SB6 glass with 1 wt \% Pu prepared under well-mixed ("Wiggle Bug") conditions and minimally-mixed ("Hand mixed") conditions. Relative peak intensities provide an indication of concentration of $\mathrm{Pu}$ in the glass. Note: "Unmixed Pu" in

figure refers to the area in the minimally-mixed sample containing undissolved $\mathrm{PuO}_{2}$.

\subsection{Durability of the Actual SB6 Glass with $1 \mathrm{wt} \% \mathrm{Pu}$}

Table 2 provides the PCT data for the actual SB6 glass containing $1 \mathrm{wt} \% \mathrm{Pu}$. Product Consistency Test data for the SB6 qualification glass are also included in Table 2. Comparing the PCT data for the SB6 glass with $1 \mathrm{wt} \% \mathrm{Pu}$ to the SB6 qualification glass indicated that incorporation of $1 \mathrm{wt} \% \mathrm{Pu}$ in the glass had no effect on glass durability as measured by the PCT. Both glasses showed normalized elemental release values for B that were better than an order of magnitude lower than the EA glass. The EA glass is the benchmark glass used for HLW glass repository disposition. The normalized release of $\mathrm{Pu}$ from the glass was very low. 
Table 2. PCT Results for SB6 Qualification Glass and SB6 Glass with 1 wt \% Pu

\begin{tabular}{|c|c|c|c|c|c||}
\hline Glass ID & $\begin{array}{c}\text { NL (B) } \\
\mathbf{g} / \mathbf{L}\end{array}$ & $\begin{array}{c}\mathbf{N L}(\mathbf{N a}) \\
\mathbf{g} / \mathbf{L}\end{array}$ & $\begin{array}{c}\mathbf{N L}(\mathbf{L i}) \\
\mathbf{g} / \mathbf{L}\end{array}$ & $\begin{array}{c}\mathbf{N L}(\mathbf{S i}) \\
\mathbf{g} / \mathbf{L}\end{array}$ & $\begin{array}{c}\mathbf{N L}(\mathbf{P u}) \\
\mathbf{g} / \mathbf{L}\end{array}$ \\
\hline ARM & 0.47 & 0.49 & 0.58 & 0.27 & -- \\
\hline EA & 17.45 & 13.33 & 9.89 & 4.05 & -- \\
\hline SB6 Qual & 0.63 & 0.90 & 0.81 & 0.46 & -- \\
\hline $\begin{array}{c}\text { SB6 Qual w/ } \\
\text { 1 wt \% Pu }\end{array}$ & 0.58 & 0.70 & 0.68 & 0.42 & 0.04 \\
\hline
\end{tabular}

\subsection{Plutonium Behavior in Glass Melters}

The behavior of Pu in the DWPF glass melter was assessed by reviewing recent DWPF SB4 and SB5 glass pour stream sample data and comparing it to expected concentrations in the DWPF feed (Reigel, 2010). Deviations in the Pu concentration in the pour stream sample could indicate $\mathrm{Pu}$ volatility from the melt or settling in the melter. The analysis of the pour stream glass data from SB4 and SB5 against expected concentrations indicated that there was no volatility or settling of $\mathrm{PuO}_{2}$ in the melter during processing (Table 3). It must be noted that these concentrations were much lower than tested in the current study. Nevertheless, these melter data are thought to give an indication of the fate of Pu during processing within the DWPF.

Table 3. Results of Pour Stream Pu Concentration Measurements for Two Melter Campaigns.

\begin{tabular}{|c|c|c|}
\hline $\begin{array}{c}\text { Melter } \\
\text { Campaign }\end{array}$ & $\begin{array}{c}\text { Targeted Pu } \\
\text { Concentration }\end{array}$ & $\begin{array}{c}\text { Pour Stream } \\
\text { Pu Concentration }\end{array}$ \\
\hline SB4 & $0.0078 \mathrm{wt} \%$ & $0.0086 \mathrm{wt} \%$ \\
\hline SB5 & $0.015 \mathrm{wt} \%$ & $0.013 \mathrm{wt} \%$ \\
\hline
\end{tabular}

Additional analyses of testing conducted at SRNL using the Cylindrical Induction Melter (CIM) for processing of lanthanide borosilicate (LaBS) glasses provides further evidence that $\mathrm{PuO}_{2}$ would not be expected to volatilize from the melt (Jones, 2006). In this testing, $\mathrm{HfO}_{2}$ was used as a surrogate for $\mathrm{PuO}_{2}$ at a concentration to represent $9.5 \mathrm{wt} \% \mathrm{PuO}_{2}$ on an equivalent molar basis. The LaBS glass was processed at nominally $1450{ }^{\circ} \mathrm{C}$ (a temperature significantly higher than DWPF melter process temperatures and a temperature that would promote volatility if it were to occur). Mass balance data indicated that $\mathrm{HfO}_{2}$ was retained at better than $99.999 \%$ in the glass. 


\subsection{Conclusions}

The literature review provided useful information regarding the solubility of $\mathrm{Pu}$ in borosilicate glass compositions as well as the effect of $\mathrm{Pu}$ on glass properties and performance. The literature review provided a bases that incorporation of $1 \mathrm{wt} \% \mathrm{Pu}$ in a borosilicate glass would be feasible.

The results of the testing indicated that at $1 \mathrm{wt} \% \mathrm{Pu}$ in a DWPF type borosilicate glass, the $\mathrm{Pu}$ was homogeneously distributed and did not result in any formation of plutonium-containing crystalline phases as long as the glass was prepared under well-mixed conditions. The incorporation of $1 \mathrm{wt} \% \mathrm{Pu}$ in the glass did not adversely impact glass viscosity (as assessed using Hf surrogate) or glass durability as measured by the PCT. Finally, evaluation of DWPF glass pour samples showed that $\mathrm{Pu}$ concentrations in the glass pour stream were close to targeted compositions in the melter feed indicating that $\mathrm{Pu}$ neither volatilized from the melt nor stratified in the melter at the Pu concentrations processed in the DWPF melter.

\subsection{Recommendations for Future Work}

A concurrent study is underway to evaluate the behavior of plutonium and neutron absorbers in waste solutions and the DWPF melter feed. When those studies are completed, the results of that work and the results presented in this report should be combined to further determine the feasibility of processing significant quantities of plutonium in DWPF. This would be consistent with the current approach used to qualify processing a new waste stream in DWPF. However, it must be noted that an assessment of any additional or new work to support repository qualification of a glass with increased concentrations of $\mathrm{Pu}$ needs to be made. 
SRNL-STI-2010-00766

Revision 0

\subsection{References}

ASTM C-1285, 2002, "Standard Test Methods for Determining Chemical Durability of Nuclear Waste Glasses: The Product Consistency Test (PCT)," ASTM C-1285, American Society for Testing and Materials (ASTM), West Conshohocken, PA.

Bates, J. K., J. W. Emery, J. C. Hoh and T. R. Johnson, 1995, "Performance of High Plutoniumcontaining Glasses for the Immobilization of Surplus Fissile Materials," in Environmental Issues and Waste Management Technologies in the Ceramic and Nuclear Industries," Edited by V. Jain and R. Palmer, Ceramic Transactions, Vol. 61, American Ceramic Society, p. 447.

Bates, J. K., A. J. G. Ellison, J. W. Emery and J. C. Hoh, 1996, "Glass as a Waste Form for the Immobilization of Plutonium," in Scientific Basis for Nuclear Waste Management XIX, Edited by W. M. Murphy and D. A. Knecht, Materials Research Society Proceedings, Materials Research Society, Vol. 412, p. 57.

Bonniaud, R. A., N. R. Jacquet-Francillon and C. G. Sombret, 1980, "The Behavior of Actinides in $\alpha$-Doped Glasses as Regards to the Long Term Disposal of High Level Radioactive Materials," in Scientific Basis for Nuclear Waste Management, Edited by C. J. M. Northrup, Jr., Vol. 2, Plenum Press, New York, p. 117.

Caurant, P., P. Loiseau, O. Majerus, V. Aubin-Chevaldonnet, I. Bardez, A. Quintas, 2009, "Glasses, Glass-Ceramics and Ceramics for Immobilization of Highly Radioactive Nuclear Waste," Nova Science Publishers, Inc., New York.

Crawford, C. L., J. C. Marra and N. E. Bibler, 2007, "Glass Fabrication and Product Consistency Testing of Lanthanide Borosilicate Glass for Plutonium Disposition," Journal of Alloys and Compounds, Vol. 444-445, p. 569.

Deschanels, X., S. Peuget, J. N. Cachia and T. Charpentier, 2007, "Plutonium Solubility and SelfIrradiation Effects in Borosilicate Glass," Progress in Nuclear Energy, Vol, 49, p. 623.

Demonie, M. and H. Cuyvers,1996, "On the Feasibility of Vitrifying High-level Liquid Waste Containing High Amounts of Plutonium," in Disposal of Weapons Plutonium - Approaches and Prospects, Edited by E. R. Merz and C. E. Walter, Kluwer Academic Publishers, Dordrecht, p. 155.

Furuya, H., S. Muraoka and T. Muromura, 1996, "Feasibility of Rock-like Fuel and Glass Waste Form for Disposal of Weapons Plutonium," in Disposal of Weapons Plutonium - Approaches and Prospects, Edited by E. R. Merz and C. E. Walter, Kluwer Academic Publishers, Dordrecht, p. 107.

Hess, N. J., W. J. Weber and S. D. Conradson, 1998a, "U and Pu L $\mathrm{L}_{\mathrm{iii}}$ XAFS of Pu-doped Glass and Ceramic Waste Forms," Journal of Alloys and Compounds, Vol. 271-273, p. 240.

Hess, N. J., W. J. Weber and S. D. Conradson, 1998b, "X-ray Absorption Fine Structure of Aged, Pu-doped Glass and Ceramic Waste Forms," Journal of Nuclear Materials, Vol. 254, p. 175. 
Jones, T. M., J. R. Zamecnik, D. H. Miller, D. T. Herman and J. C. Marra, 2006, "Pu Immobilization - Induction Melting and Off-gas Testing, WSRC-TR-2006-00458, Washington Savannah River Company, Aiken, SC.

Jouan, A., 1996, "French Appraisal of the Vitrification Option: Weapons Plutonium - or How to Get Rid of It!" in Disposal of Weapons Plutonium - Approaches and Prospects, Edited by E. R. Merz and C. E. Walter, Kluwer Academic Publishers, Dordrecht, p. 197.

Karraker, D. G., 1982, "Actinide Valences in Borosilicate Glass," Journal of the American Ceramic Society, Vol. 65, p. 53.

Lopez, C., X. Deschanels, J.M. Bart, J.M. Boubals, C. Den Auwer, E. Simoni, 2003, "Solubility of actinide surrogates in nuclear glasses Journal of Nuclear Materials, 312, p. 76.

Lutze, W, ,R. C. Ewing, editors, 1988, "Radioactive Waste Forms For The Future," NorthHolland publishing, Amsterdam.

Marples, J. A. C., 1996, "Vitrification of Plutonium for Disposal," in Disposal of Weapons Plutonium - Approaches and Prospects, Edited by E. R. Merz and C. E. Walter, Kluwer Academic Publishers, Dordrecht, p. 179.

Marra, J. C., 2006, "Development of an Alternative Glass Formulation for the Vitrification of Excess Plutonium," WSRC-TR-2006-00031, Washington Savannah River Company, Aiken, SC.

Marra, J.C., A.D. Cozzi, C.L. Crawford, C.C. Herman, J.E. Marra and D.K. Peeler, 2009, "Development of Glass and Crystalline Ceramic Forms for Disposition of Excess Plutonium," in Proceedings of the 2009 International Symposium on Radiation Safety Management, Daejeon, Republic of Korea, 2009.

Maslakov, K. I., S V. Stefanovsky, A. Yu. Teterin, Yu. A. Teterin and J. C. Marra, 2009, "X-ray Photoelectron Study of Lanthanide Borosilicate Glass," Glass Physics and Chemistry, Vol. 35, No. 1, p. 22.

Matyunin, Yu. I., V. V. Kushnikov and A. V. Demin, 1996, "Possible Ways of the Weapon Plutonium Processing to Produce the Steady Glass Materials Suitable for Further Safe Disposal," in Disposal of Weapons Plutonium - Approaches and Prospects, Edited by E. R. Merz and C. E. Walter, Kluwer Academic Publishers, Dordrecht, p. 123.

Matzke, Hj. And J. van Geel, 1996, "Incorporation of $\mathrm{Pu}$ and Other Actinides in Borosilicate Glass and in Waste Ceramics," in Disposal of Weapons Plutonium - Approaches and Prospects, Edited by E. R. Merz and C. E. Walter, Kluwer Academic Publishers, Dordrecht, p. 93.

Mertz, C. J., A. J. Bakel, J. K. Bates, D. B. Chamberlain, J. A. Fortner, J. M. Hanchar and S. F. Wolf, 1998, "Comparison of the Corrosion Behavior of Plutonium Glasses," in Environmental Issues and Waste Management Technologies in the Ceramic and Nuclear Industries III," Edited by D. K. Peeler and J. C. Marra, Ceramic Transactions, Vol. 87, American Ceramic Society, p. 211.

Muller, I. and W. J. Weber, September 2001, "Plutonium in Crystalline Ceramic and Glasses," MRS Bulletin, p. 698. 
Pareizs, J. M., B. R. Pickenheim, C. J. Bannochie, A. L. Billings, N. E. Bibler and D. R. Click, 2010, "Sludge Washing and Demonstration of the DWPF Flowsheet in the SRNL Shielded Cells for Sludge Batch 6 Qualification," SRNL-STI-2010-00353, Savannah River National Laboratory, Aiken, SC.

Peuget, S., V. Broudic, C. Jegou, P. Frugier, D. Roudil, X. Deschanels, H. Rabiller and P. Y. Noel, 2007, "Effect of Alpha Radiation on the Leaching Behavior of Nuclear Glass," Journal of Nuclear Materials, Vol. 362, p. 474.

Peuget, S., J.-N. Cachia, C. Je'gou, X. Deschanels, D. Roudil, V. Broudic, J.M. Delaye, J.-M. Bart, 2006, "Irradiation stability of R7T7-type borosilicate glass," Journal of Nuclear Materials, Vol. 354, p. 1.

Plodinec, M. J., 1979, "Development of Glass Compositions for Immobilization of SRP Waste," DP-1517, Savannah River Plant, Aiken, SC.

Reigel, M. M. and N. E. Bibler, 2010, "Sludge Washing and Demonstration of the DWPF Flowsheet in the SRNL Shielded Cells for Sludge Batch 6 Qualification," SRNL-STI-201000435, Savannah River National Laboratory, Aiken, SC.

Shiryaev, A.A., Ya. V. Zubabichus, S. V. Stefanovsky, A. G. Ptashkin, and J. C. Marra, "XAFS of $\mathrm{Pu}$ and $\mathrm{Hf} \mathrm{L}_{\mathrm{III}}$ Edge in Lanthanide-Borosilicate Glass"; pp. 259-265 in Materials Research Society Symposium Proceedings, Vol. 1193, in Scientific Basis for Nuclear Waste Management XXXIII, Edited by B. E. Burakov and A. S. Aloy. Materials Research Society, Warrendale, PA, 2009.

Stefanovsky, S. V., A. A. Shiryaev, A G. Ptashkin and J. C. Marra, 2007, "Preparation and Examination of the Pu-bearing LaBS Glass," Final Report on Subcontract AC59537T with Washington Savannah River Company, Daymos, Ltd., Moscow, Russia.

Vernaz E. Y. and N. Godon, 1992, "Leaching of Actinides from Nuclear Waste Glass: French Experience," in Scientific Basis for Nuclear Waste Management XV, Edited by C. Sombret, Materials Research Society Proceedings, Materials Research Society, Vol. 257, p. 37.

Weber, W. J, R. C. Ewing, C. A. Angell, G. W. Arnold, A. N. Cormack, J. M. Delaye, D. L. Griscom, L. W. Hobbs, A. Navrotsky, D. L. Price, A. M. Stoneham, M. C. Weinberg, 1997, "Radiation effects in glasses used for immobilization of high-level waste and plutonium disposition," Journal of Materials Research, Vol. 12, No. 8, p. 1946

Wellman, D. M, J.P. Icenhower, W.J. Weber, 2005, "Elemental dissolution study of Pu-bearing borosilicate glasses" Journal of Nuclear Materials, Vol. 340, p. 149.

Wicks, G. G., J. M. McKibben, M. J. Plodines and W. G. Ramsey, 1996, "SRS Vitrification Studies in Support of the U.S. Program for Disposition of Excess Plutonium," in Disposal of Weapons Plutonium - Approaches and Prospects, Edited by E. R. Merz and C. E. Walter, Kluwer Academic Publishers, Dordrecht, p. 143.

D.J. Wronkiewicz, 1994, in Scientific Basis for Nuclear Waste Management XVII, Materials Research Society Proceedings, Materials Research Society, Vol. 333, p. 83. 


\section{Appendix A. Summary of Glass Compositions from Previous Pu Studies}

\begin{tabular}{|c|c|c|c|c|c|c|c|c|c|c|c|c|c|c|c|c|c|c|c|}
\hline Oxide & $\begin{array}{l}\text { Bates } \\
1995\end{array}$ & $\begin{array}{c}\text { Bates } \\
1996 \\
\text { Mertz }\end{array}$ & Plodinec & Marples & Karraker & Hess & Deschanels & Deschanels & Peuget & Vernaz & Bonniaud & Bonniaud & Matzke & Furuya & Marra $^{* *}$ & $\begin{array}{l}\text { Vienna } \\
\text { (Frit A) }\end{array}$ & $\begin{array}{l}\text { Marra } \\
\text { (Frit X) }\end{array}$ & $\begin{array}{l}\text { Crawford } \\
\text { (Frit B) }\end{array}$ & Matyunin \\
\hline $\mathrm{Al}_{2} \mathrm{O}_{3}$ & 3.8 & 2.2 & 11.6 & 5.0 & -- & 6.0 & 5 & 4.3 & 4.9 & 0.1 & -- & -- & 2.3 & 4.89 & 9.0 & 21.5 & 10.0 & 21.5 & $\begin{array}{l}18.9- \\
22.9\end{array}$ \\
\hline $\mathrm{B}_{2} \mathrm{O}_{3}$ & 7.8 & 8.9 & 8.3 & $11-21.9$ & 11.1 & 7.0 & $14-15$ & 18 & 14 & 19 & 19.4 & 20.1 & 10.7 & 13.90 & 6.0 & 11.7 & 13.0 & 11.6 & -- \\
\hline $\mathrm{CaO}$ & 1.2 & -- & 5.0 & -- & 5.6 & 2.0 & 4 & 5.2 & 4.0 & -- & -- & -- & 3.5 & 4.00 & 2.0 & -- & -- & -- & -- \\
\hline $\mathrm{Fe}_{2} \mathrm{O}_{3}$ & 11.7 & -- & 7.9 & 2.7 & -- & 10.0 & 3 & -- & 3.0 & 0.6 & -- & -- & 0.3 & 2.90 & 12.0 & -- & -- & -- & -- \\
\hline $\mathrm{Gd}_{2} \mathrm{O}_{3}$ & $0-2$ & 3.8 & -- & -- & -- & -- & -- & -- & -- & -- & -- & -- & -- & -- & -- & 8.6 & 13.5 & 12.8 & -- \\
\hline $\mathrm{HfO}_{2}$ & -- & -- & -- & -- & -- & -- & -- & -- & -- & -- & -- & -- & -- & -- & -- & -- & 7.0 & 6.6 & \\
\hline $\mathrm{K}_{2} \mathrm{O}$ & 3.6 & 7.7 & -- & -- & -- & -- & -- & -- & -- & -- & -- & -- & -- & -- & -- & -- & -- & -- & -- \\
\hline $\mathrm{La}_{2} \mathrm{O}_{3}$ & -- & -- & -- & -- & -- & -- & $3-4^{*}$ & -- & $1-4^{*}$ & -- & -- & -- & -- & $1.00^{*}$ & -- & 12.4 & 19.0 & 8.1 & -- \\
\hline $\mathrm{Li}_{2} \mathrm{O}$ & 4.3 & 3.9 & -- & $3.7-4$ & 4.4 & 4.9 & 2 & 2.6 & 2.0 & -- & -- & -- & -- & 2.00 & 5.0 & -- & -- & -- & -- \\
\hline $\mathrm{MgO}$ & 1.3 & -- & -- & 6.2 & -- & 0.7 & -- & -- & -- & -- & -- & -- & 1.8 & -- & -- & -- & -- & -- & -- \\
\hline $\mathrm{MnO}_{2}$ & -- & -- & 2.6 & -- & -- & 3.0 & -- & -- & 0.4 & -- & -- & -- & -- & 0.26 & 2.0 & -- & -- & -- & -- \\
\hline $\mathrm{MoO}_{3}$ & -- & -- & -- & -- & -- & -- & $2-3$ & -- & 1.7 & -- & -- & -- & -- & 1.73 & -- & -- & -- & -- & -- \\
\hline $\mathrm{Na}_{2} \mathrm{O}$ & 7.6 & 9.2 & 9.4 & $7.7-8.3$ & 20.6 & 9.1 & $10-11$ & 7 & 10 & 9.4 & 9.5 & 9.8 & 14.9 & 9.78 & 14.0 & -- & -- & -- & 25.9 \\
\hline $\mathrm{Nd}_{2} \mathrm{O}_{3}$ & -- & -- & -- & -- & -- & -- & -- & -- & -- & -- & -- & -- & -- & -- & -- & 12.8 & 15.00 & 8.2 & -- \\
\hline $\mathrm{NiO}$ & -- & -- & 0.6 & -- & -- & 2.0 & -- & -- & 0.4 & -- & -- & -- & -- & 0.40 & -- & -- & -- & -- & -- \\
\hline $\mathrm{P}_{2} \mathrm{O}_{5}$ & -- & -- & -- & -- & -- & -- & -- & -- & 0.3 & -- & -- & -- & -- & 0.30 & -- & -- & -- & -- & $\begin{array}{l}47.8- \\
51.8\end{array}$ \\
\hline $\mathrm{SiO}_{2}$ & 49 & 45.4 & 43.7 & $41.5-51$ & 58.3 & 50.6 & $45-46$ & 59 & 45.5 & 44 & 45.4 & 47.1 & 48.3 & 45.15 & 50.0 & 29.2 & 20.00 & 28.9 & -- \\
\hline $\mathrm{SnO}$ & -- & 2.2 & -- & -- & -- & -- & -- & -- & 0.02 & & -- & -- & -- & -- & -- & -- & -- & -- & -- \\
\hline $\mathrm{SrO}$ & -- & -- & -- & -- & -- & -- & -- & -- & 0.3 & & -- & -- & -- & 0.34 & -- & 2.5 & 2.5 & 2.5-- & -- \\
\hline $\mathrm{TiO}_{2}$ & -- & 2.1 & -- & -- & -- & -- & -- & -- & -- & & -- & -- & 4.0 & -- & -- & -- & -- & -- & -- \\
\hline $\mathrm{U}_{3} \mathrm{O}_{8}$ & -- & -- & 1.5 & -- & -- & 3.0 & -- & -- & -- & & -- & -- & -- & -- & -- & -- & -- & -- & -- \\
\hline $\mathrm{ZnO}$ & -- & 3.0 & -- & -- & -- & -- & $2-3$ & 3.2 & 2.5 & & -- & -- & -- & 2.47 & -- & -- & -- & -- & -- \\
\hline $\mathrm{ZrO}_{2}$ & 0.9 & 4.9 & -- & -- & -- & 0.7 & $2-3$ & 0.7 & 2.7 & & -- & -- & -- & 2.64 & -- & -- & -- & -- & -- \\
\hline Others & 0.2 & 1.0 & 0.5 & 11.8 & -- & 1.0 & $3-4$ & -- & 2.5 & 23 & 23.1 & 19.6 & 14.3 & 7 & -- & -- & -- & -- & -- \\
\hline & & & & & & & & & & & & & & & & -- & & & \\
\hline $\mathrm{PuO}_{2}$ & $2-7$ & $\begin{array}{c}5.7- \\
8.5 \\
\end{array}$ & 7.0 & $2.5-5$ & 0.5 & 1.0 & $0.85-3.0$ & $2-4$ & 0.85 & 2.8 & 2.8 & 3.3 & $1-10$ & 0.96 & $\begin{array}{c}0.5- \\
2.0\end{array}$ & 13.4 & 9.5 & 9.5 & 3.4 \\
\hline
\end{tabular}




\section{Distribution:}

N. C. Iyer, 773-41A

S. L. Marra, 773-A

A. B. Barnes, 999-W

C. C. Herman, 999-W

J. E. Occhipinti, 704-S

J. W. Ray, 704-S

J. F. Iaukea, 704-30S

D. C. Sherburne, 704-S

A. V. Staub, 704-27S

T. L. Fellinger, 704-26S

E. W. Holtzscheiter, 704-15S

J. M. Bricker, 704-27S

H. H. Elder, 704-24S

M. T. Keefer, 766-H

K. D. Gilbreath, 766-H

J. P. Vaughan, 773-41A

J. C. Marra, 773-42A

C. L. Crawford, 773-42A

K. M. Fox, 999-W

D. K. Peeler, 999-W

A. L. Billings, 999-W

F. C. Johnson, 999-W

S. H. Reboul, 773-A

J. W. Amoroso, 999-W

S. P. Schneider, Cloverleaf 2161

G. L. Smith, Cloverleaf 2160

J. M. Ridley, 704-S

P. R. Jackson, 703-46A 